\title{
Karapınar (Konya) Yöresi Göbekli Halıları
}

\author{
Abdullah KARAÇAĞ*
}

\section{ÖZET}

Karapınar, halıcılık adına önemli eserler üretmiş dokuma merkezlerimizden birisidir. Karapınar halıları, halılara işlenmiş motiflere göre çeşitli isimler almışlardır. Bunlar arasında en bilinenleri, Direkli Karapınar, Göbekli Karapınar ve Karapınar'ın Ladik modelidir.

Göbekli Karapınar halılarında, zeminde bir ya da üç tane göbek görülür. Bu göbeklerin zemine işlenişi, cilt sanatında görülen şemse ve salbek düzenlemesini andııır. Halıları çoğunlukla tarak motifinin işlendiği tek bir kuşak çevreler. Halının kısa kenarlarında ise ev tasvirinin işlendiği ince şeritler yer alır. 18. yüzyıl Karapınar halılarında kompozisyonda genel bir sadelik hakimdir. 19. yüzyıl halılarının göbek ve kuşakları kalabalıklaşır ve farklı yörelerin desenleri görülmeye başlar. 19. yüzyıldan itibaren diğer yörelerimizin pek çoğunda olduğu gibi özelliklerini yitirmeye başlamış, günümüzde ise yok olma noktasına gelmiştir.

Anahtar Kelimeler: Karapınar, Salur, Halı, Göbek, Madalyon.

\section{Giriş̧}

Anadolu Selçuklularının başkenti olan Konya yöresi, Selçuklular döneminden beri önemli bir dokuma merkezidir. Anadolu'nun bu en eski ve önemli dokuma merkezinde halıcılık geniş bir bölgeye yayılmıştır. Makalemizde bahsedeceğimiz Karapınar, Konya'nın bu önemli dokuma merkezlerinden sadece biri olup, halıcılık adına önemli eserler üretmiştir.

Yrd. Doç. Dr., Akdeniz Üniversitesi, Edebiyat Fakültesi, Sanat Tarjhi Bölümü, Ögretim Üyesi, e-posta:abdullahkaracag@hotmail.com Assist. Prof. Doc., Akdeniz Unversity, Faculty of Fine Arts, Department of Art History.

\section{Karapınar (Konya) Carpets with Central Organization}

\section{ABSTRACT}

Karapınar is one of the important production centers of Turkey in terms of carpet weaving. The carpets of Karapınar have taken various names with respect to their motives. The most widely known examples are Direkli Karapinar, (with vertical elements in imagery) Göbekli (with a central organization) Karapinar and Ladik model of Karapinar (with imagery composed of trees).

There are one or three central cores (madalyon) in the Karapınar carpets with central organization. The style of these cores remind the şemse and salbek patterns seen in the art of bookmaking. Generally there is a single border made up of the motives of comb (tarak). There are thin ribbons carrying the imagery of houses on the short sides of the weaving. Generaly the Karapınar carpets of the 18th century have a simple and elementary composition. Whereas the carpets of the 19th century have more articulated compositions which include patterns of different regions. Like in many other regions of Turkey, these carpets have gradually lose their authentic features 19th century onwards and today they are in the stage of disappearance.

Keywords: Karapınar, Salur, Carpet, Göbek (core), Madalyon (core).

Karapınar, Anadolu'nun ortasında bir Osmanlı kasabası olarak 1560 yılında kurulmuştur. Yakınında bulunan ve zaman zaman suyu kesildiği için "kara" denildiği tahmin edilen pınardan dolayı buraya Karapınar adı verilmiştir. Osmanlı Devleti, kendi olanaklarıyla ayakta kalması mümkün olmayan bu yeri kalkındırmak maksadıyla kasabanın içinde bir külliye yaptı- 
rıp buraya zengin vakıflar tahsis etmiştir. 1563'te külliyenin inşasının tamamlanmasından hemen sonra Karapınar'a Sultaniyye de denmeye başlanmıştır.

Özellikle resmi kaynaklarda geçen Sultaniyye ismi 1934 yılında Karapınar olarak değiştirilmiştir. Diğer taraftan Karapınar'da iskânı özendirmek için buraya yerleşenlere ekonomik ve idari özerklik tanınmıştır. Karapınar, Sultan Selim Külliyesi'nin, Konya ovasında geniş bir alana yayılan vakıf arazisinden elde edilen ve önemli miktarlara ulaşan gelirlerin toplandığı merkez haline getirilmiştir. Ancak tüm bu çabalara rağmen, verimsiz toprakları ve çetin tabiat şartları dolayısıyla Karapınar günümüze kadar hep küçük bir kasaba olarak kalmıştır. ${ }^{1}$

Karapınar'ın bu verimsiz ve kurak toprakları, kü çükbaş hayvanların otlamasına müsaittir. Geçmişte ve günümüzde Karapınar'da hayvancılık, halk için önemli bir gelir kaynağı olmuştur. ${ }^{2}$ Geçiminin büyük bir kısmını hayvancılıktan elde eden Karapınar halkı, hayvanlarından elde ettikleri yünlerle dokudukları halılarında, Karapınar'a özgü eserler verip, Orta Anadolu halıcılık merkezleri içinde adından önemle söz ettirmişlerdir.

Karapınar ve civar köylerde dokunan halıların ortak özellikleri kullandıkları malzemenin saf yün olmasıdır. Koyun ve kuzuların yünleri yıkanıp temizlendikten sonra taraklardan geçirilerek "süme" haline getirilir. Sümeler "kirman" ve "iğg" denen basit aletlerle eğrilir. Eğrilen ipler ikiye katlanarak "çıkrık" larda bükülür. Bu şekilde hazırlanan ipler "gelep" yapıldıktan sonra doğal boyalarla renklendirilir. ${ }^{3}$ Karapınar ve yöresinde bitkilerden kök boya elde etme işlemine "çöpboya" veya "kökboya" denir. ${ }^{4}$ Boyadan çıkan iplerden yumaklar yapılır. Daha sonra dokumada kullanılmak üzere yumaklar "Melik" ler şeklinde küçültülür. ${ }^{5}$ Bu çalışmalardan sonra hazır hale gelen malzeme ile Türk düğümü atılarak halılar dokunur. $^{6}$

Karapınar halıları, ebatlarına ve kullanıldıkları yerlere göre "Sergi Halıları", "Mobilya Halıları", "Divan Halıları", "Duvar Halıları", "Seccadeler", "Yastık Yüzleri" gibi çeşitli isimler almışlardır. ${ }^{7}$

Yusuf Küçükdağ, “Karapınar Kasabasının Kurulması ve İskan Durumu", Turkiuge Büyü̈k Millet Meclisi nin Açılşınn 80. Yildönümü Karapinar Sempozyumu (Karapinar, 26-27 Ekim 2000). Editör: Yusuf Küçükdağ, Konya 2001, s. 8-15; Detayl bilgi için bkz: İbrahim Gündüz, Bütün Yönleriyle Karapınar, Konya 1980

2 İbrahim Gündüz, age., s. 388.

3 İbrahim Gündüz, age., s. 414-415 ; Fulya Bodur, "Karapınar Halıcılığı", Turk Diinyast Araştırmalart, Türk Haliları Özel Sizısı, Say1 32, İstanbul, 1984, s. 74 ; İbrahim Gündüz, Karapmar El Dokumalan ve Kökboyachlk, Karapınar Belediyesi Kültür Yayını No. : 2, Konya 1993, s. 13-16.

4 İbrahim Gündüz, age., 1993, s. 17.

5 İbrahim Gündüz, age, 1980, s. 415

6 Fulya Bodur, agm, s. 76 ; İbrahim Gündüz, 1993, s. 38

7 İbrahim Gündüz, age, 1980, s. $410-411$; İbrahim Gündüz; age. $1993,41-42$
Karapınar ve köylerinde dokunan halı ve seccadelerin desen itibari ile çeşitli isimler aldığı görülmektedir. Bu isimleri "Bademli”, "Selçuk", "Çiçekli”, "Köşe Göbek", "Cicil Göbek”, "Çavuşlu", "Mihraplı", "Bulutlu", "Serpme Çiçek", "Kapalı Cıngırdak", "Üç Toplu”, "Kaneviçeli”, "Kelebekli”, "Saksılı”, “Taşpınar Modeli”, “Beş Parmak", “Direkli”, "Kongurdaklı", "Yıldız Ayak”, “Kırk Kız Örneği”, “Mezar Taşlı”, “Hadili”, “Beyaz Toplu", ve "Kaymakamlı" olarak sıralamak mümkündür. ${ }^{8}$ Görüldüğü üzere Karapınar'da halı dokuyanlar, halılarına, işledikleri desenlere göre isimler vermişlerdir. Bu desenlerden en yaygın kullanım bulan Karapınar halıları ise "Direkli Karapınar", "Göbekli Karapınar" ve Karapınar'ın Lâdik modeli" dir.

Göbekli Karapınar halıları olarak bilinen halı grubu makalemizin asıl konusunu oluşturmaktadır. Aynı yöreye ait, halk arasında Salur modeli olarak bilinen halı örnekleri de göbekli tasarımları dolayısıyla, çalışmamıza dâhil edilmiştir.

Salur köyü, Karapınar-Gölören karayolu üzerinde olup, ilçeye $18 \mathrm{~km}$ uzaklıktadır. ${ }^{9}$ Salur kelimesi Türk tarihinden bahseden kaynaklarda sık sık karşımıza çıkmaktadır. Oğuz mitolojisinde Oğuz Han'ın altı oğlu vardır. Bunlardan Tağ-Han'ın büyük oğlunun adı Salur'dur. ${ }^{10}$ Salurlar Oğuzlar in 24 boyundan birinin adıdır. Salurlar, Anadolu'nun iskânında geniş ölçüde rol oynamış, Kadı Burhaneddin gibi büyük bir şahsiyet yetiştirmiş ve Oğuzlar'ın tarihinde mühim roller oynamış boylardan biridir. Konya bölgesi, Salur yer adlarının en çok bulunduğu bölgelerden biridir. ${ }^{11}$ Türkler gittikleri yerlere boylarının, kavimlerinin isimlerini vermişlerdir. Karapınar'ın Salur Köyü de ismini Salur boyundan almıştır. Halı-kilim dokumacılığının ön plana çıktığı köy, Salur halısıyla tanınmaktadır.

\section{Karapınar (Konya) Yöresi Göbekli Halıları (Katalog)}

Örnek 1: Yarım bir halı parçasıdır. Kalan kısmından anlaşıldığına göre üç göbekli tipik 18.yüzyıla tarihlenebilen Karapınar Salur halısıdır. Yün iplikle, Türk düğüm tekniği kullanılarak dokunmuştur. Ebatlar1 138x410cm.dir. Zeminde dört kollu göbek bulunmaktadır. Dört kollu göbeğin etrafı çengellerle çevrelenmiştir. Zeminde görülen üç büyük göbek birbirine küçük göbeklerle bağlanmıştır. Halıyı tarak motifli tek kuşak çevrelemektedir. Halının alt ve üst kenarlarında ki şeritlerde ise yan yana sıralanmış ev desenleri görülmektedir. Halı çivit mavisi, kırmızı, beyaz ve kahverengi ipliklerle dokunmuştur (Foto 1).

8 İbrahim Gündüz, age., 1980, s. 412

9 İbrahim Gündüz, age., 1980, s. 517

10 Bahaeddin Ögel, Tkirk Mitolojisi, Cilt I, Türk Tarih Kurumu, Ankara 1989 , s. $212-213$

1 I Faruk Sümer, Oguzlar (Tirkmenler) Tarihleri-Boy Teşkilat -Destanlar.. Türk Dünyası Araştırmaları Vakfı. İstanbul 1992, s. 249-253. 


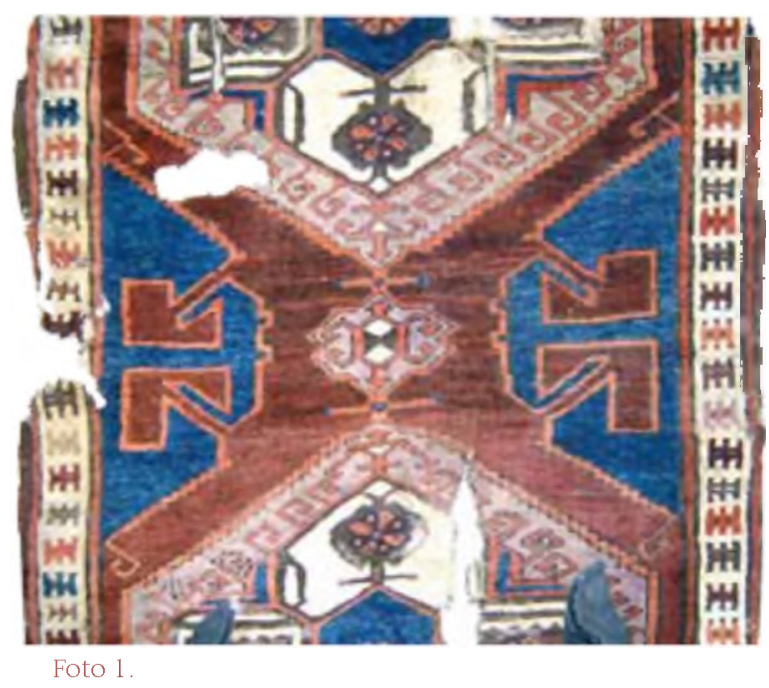

Örnek 2: 18. yüzyıldan kaldığı tahmin edilen Salur halısıdır. Yün iplikle, Türk düğüm tekniği kullanılarak dokunmuştur. Ebatları 148x182 cm. dir. Zeminde dört kollu göbek bulunmaktadır. Dört kollu göbeğin etrafı çengellerle çevrelenmiştir. Göbeğin iki ucunda birbirine paralel iki küçük göbek bulunmaktadır. Bu küçük göbekler elibelinde motifi ile sonlanmaktadır. Halıyı tarak motifli tek kuşak çevreler. Halının alt ve üst kenarlarında ki şeritlerde yan yana sıralanmış ev desenleri görülmektedir. Halı çivit mavisi, kırmızı, beyaz, kahverengi, pembe ve açık sarı renkli ipliklerle dokunmuştur (Foto 2).

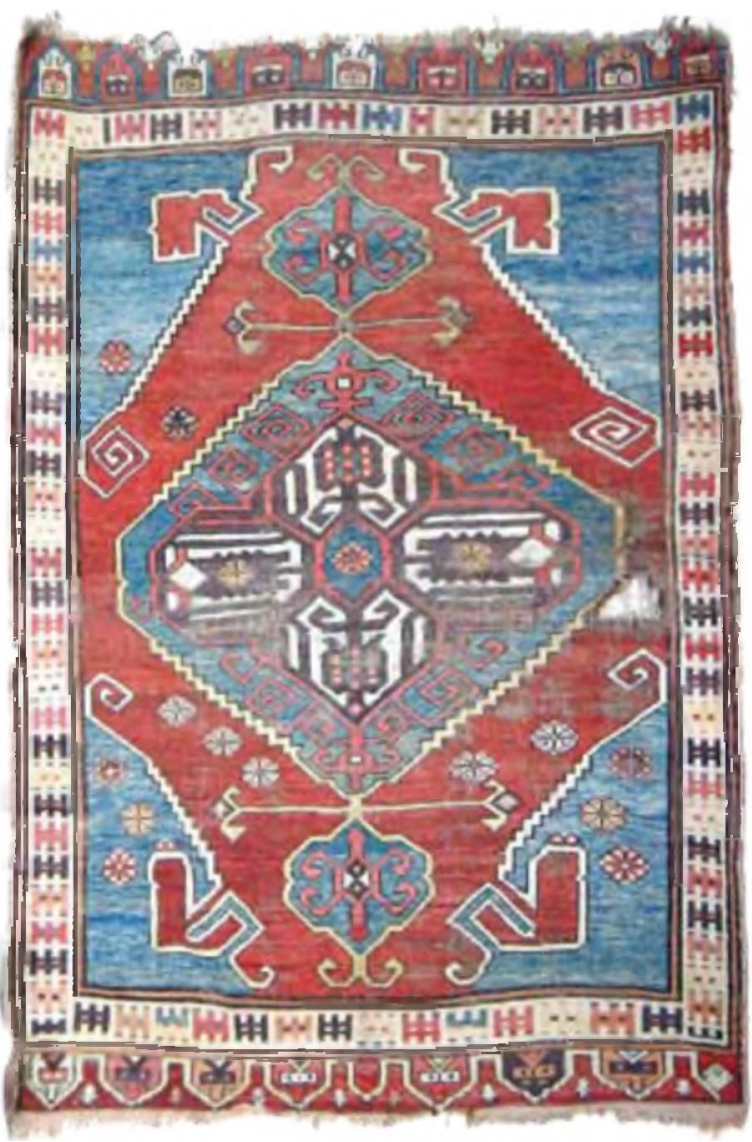

linto $)$
Örnek 3: Halıda yer yer sökülmeler vardır. 18. yüzyıla tarihlenebilen Salur halısıdır. Yün iplikle, Türk düğüm tekniği kullanılarak dokunmuştur. Ebatları $146 \times 248 \mathrm{~cm}$. dir. Zeminde dört kollu büyükçe bir göbek ve göbeğin etrafında geometrik şekiller görülmektedir. Halıyı stilize çiçek motifli geniş bir kuşak çevreler. Halı kırmızı, mavi, krem, siyah ve beyaz renkli ipliklerle dokunmuştur (Foto 3).

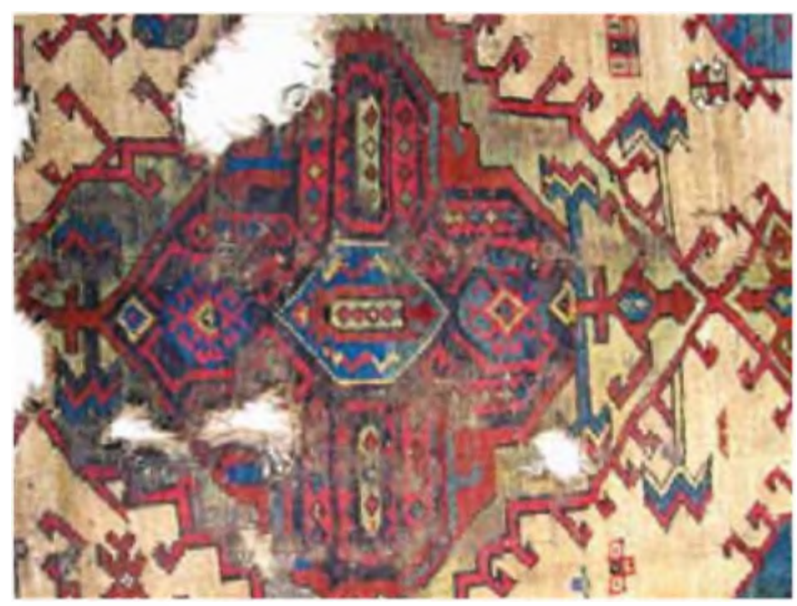

Foto 3

Örnek 4: 18. yüzyıla tarihlenebilen Salur halısıdır. Yün iplikle, Türk düğüm tekniği kullanılarak dokunmuştur. Ebatları $126 \times 380 \mathrm{~cm}$. dir. Zeminde dört kollu göbek bulunmaktadır. Dört kollu göbeğin etrafı çengellerle çevrelenmiştir. Göbeğin iki ucunda birbirine paralel iki küçük göbek bulunmaktadır. Halıyı tarak motifli tek kuşak çevreler. Halının alt ve üst kenarlarında ki şeritlerde ev desenleri görülmektedir. Halı çivit mavisi, kırmızı, beyaz, kahverengi, pembe, açık sarı ve yeşil renkli ipliklerle dokunmuştur (Foto 4).

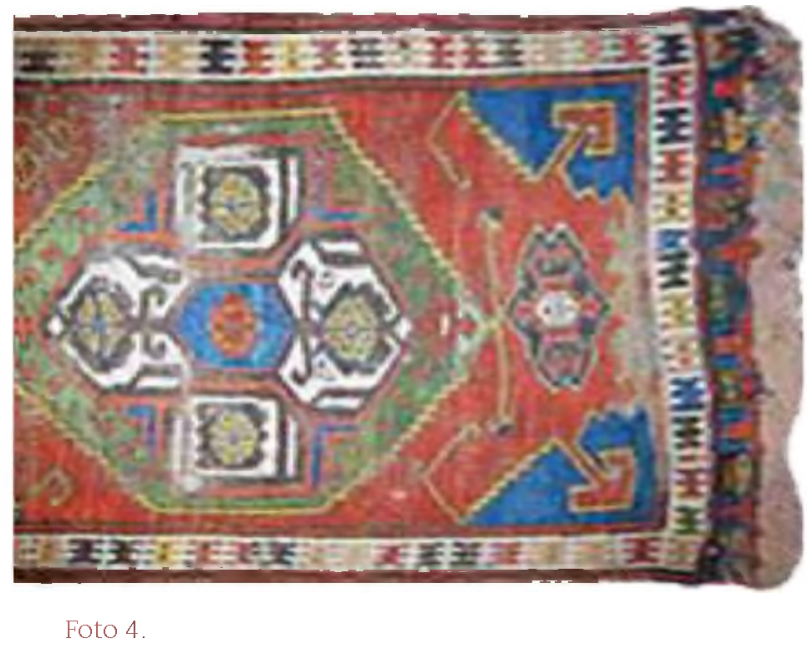

Örnek 5: Üç göbekli, 18.yüzyıla tarihlenebilen Karapınar Salur halısıdır. Yün iplikle, Türk düğüm tekniği kullanılarak dokunmuştur. Ebatları $135 \times 410 \mathrm{~cm}$. dir Zeminde dört kollu göbek bulunmaktadır. Dört kollu göbeğin etrafı çengellerle çevrelenmiştir. Zeminde görülen üç büyük göbek birbirine küçük göbekler- 
le bağlanmıştır. Halıyı tarak motifli tek kuşak çevrelemektedir. Halının alt ve üst kenarlarında ki şeritlerde ev desenleri görülmektedir. Halı çivit mavisi, kırmızı, beyaz, kahverengi, pembe, siyah, açık sarı ve yeşil renkli ipliklerle dokunmuştur (Foto 5)

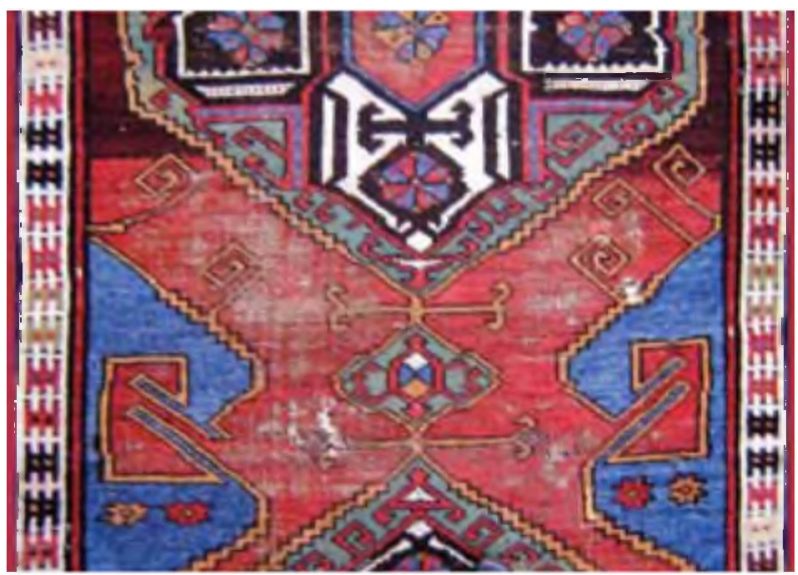

Foto 5 .

Ömek 6: Halı oldukça yıpranmıştır. 18. yüzyıla tarihlenebilen göbekli Karapınar halısıdır. Yün iplikle, Türk düğüm tekniği kullanılarak dokunmuştur. Ebatlar1 $125 \times 171 \mathrm{~cm}$. dir. Zeminde büyükçe bir göbek görülmektedir. Göbeğin her iki kenarında bulunan, lale benzeri stilize çiçek motifi ile nihayetlenmektedir. Halının üç köşesinde hayat ağacı motifi görülmektedir. Muhtemelen dördüncü köşesinde de hayat ağacı motifi vardı fakat sökülme olduğu için görülmüyor. Halıyı geniş bir kuşak çevreliyor. Kuşakta zikzak şekillerin içerisi stilize çiçek motifleri ile süslenmiştir. Stilize çiçek motiflerinin her iki yanında elibelinde motifi görülmektedir. Halının alt ve üst kenarlarında ki şeritlerde ev desenleri bulunmaktadır. Halı kırmızı, sarı, mavi, yeşil, mor ve beyaz renkli ipliklerle dokunmuştur (Foto 6).

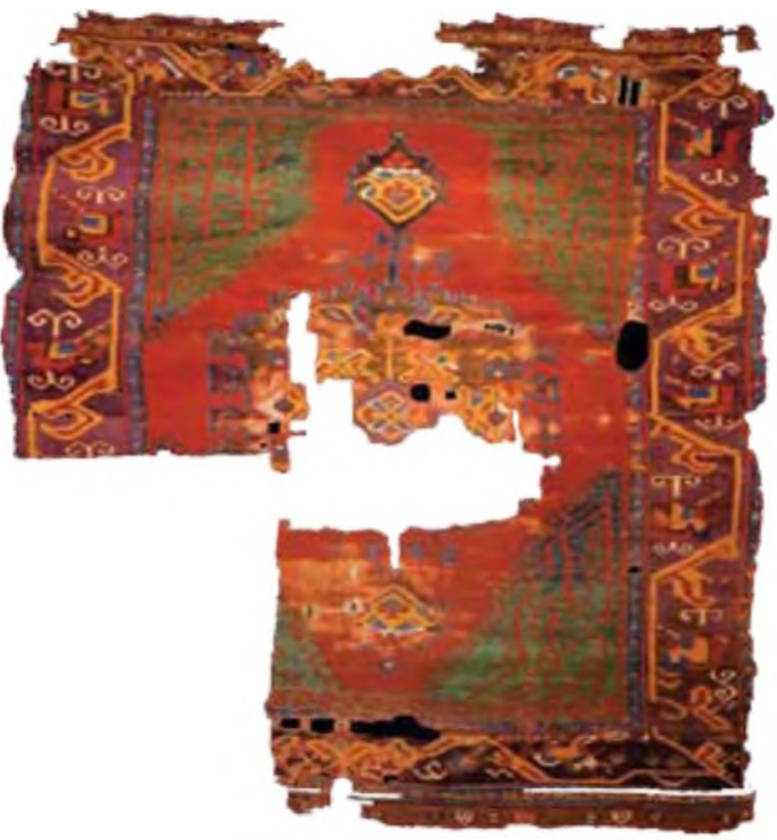

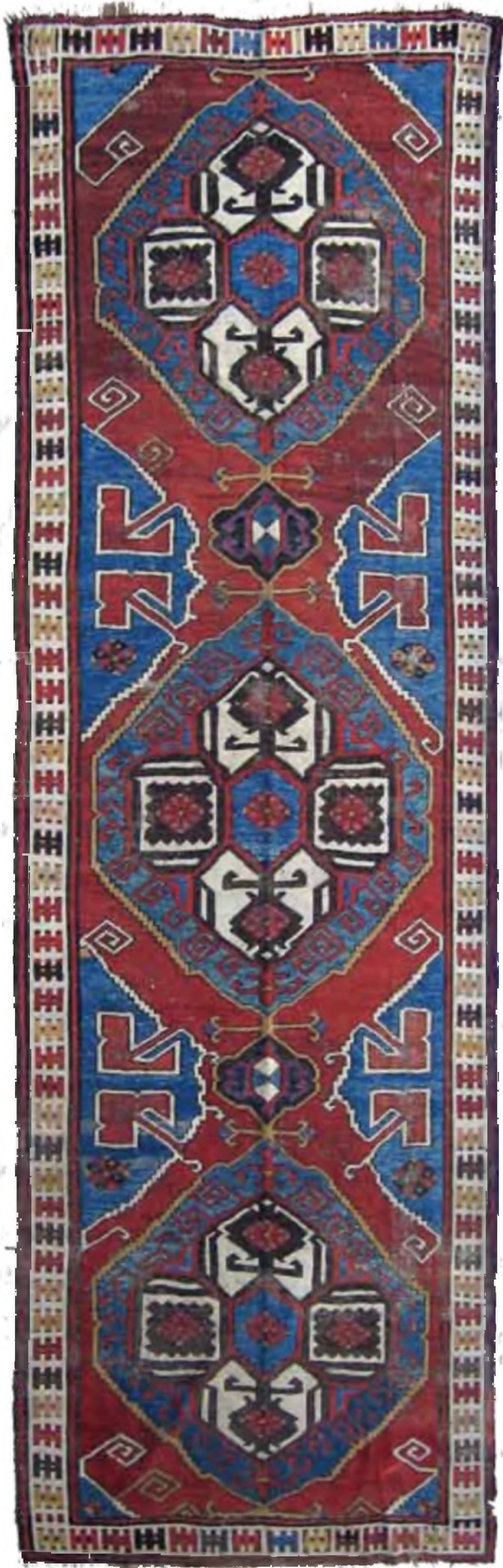

Foto 7 


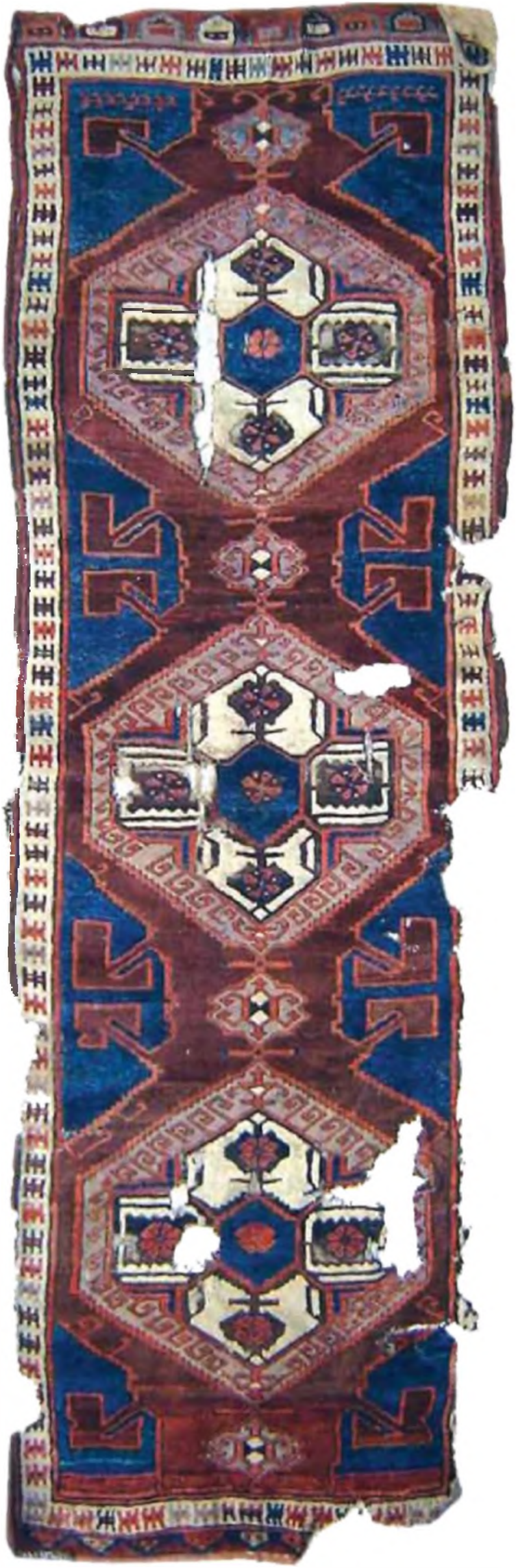

Örnek 7: Üç göbekli, 18. yüzyıla tarihlenebilen Karapınar Salur halısıdır. Yün iplikle, Türk düğüm tekniği kullanılarak dokunmuştur. Ebatlanı $146 \times 410 \mathrm{~cm}$. dir. Zeminde dört kollu göbek bulunmaktadır. Dört kollu göbeğin etrafı çengellerle çevrelenmiştir. Zeminde görülen üç büyük göbek birbirine küçük göbeklerle bağlanmıştır. Halıyı tarak motifli tek kuşak çevrelemektedir. Halı çivit mavisi, kırmızı, beyaz, siyah ve açık kahverengi ipliklerle dokunmuştur (Foto 7).

Örnek 8: Üç göbekli 18.yüzyıla tarihlenebilen Karapınar Salur halısıdır. Yün iplikle, Türk düğüm tekniği kullanılarak dokunmuştur. Ebatları $135 \times 392 \mathrm{~cm}$. dir. Zeminde dört kollu göbek bulunmaktadır. Dört kollu göbeğin etrafı çengellerle çevrelenmiştir. Zeminde görülen üç büyük göbek birbirine küçük göbeklerle bağlanmıştır. Halıyı tarak motifli tek kuşak çevrelemektedir. Halının alt ve üst kenarlarında ki şeritlerde ev desenleri görülmektedir. Halı çivit mavisi, kırmızı, beyaz ve kahverengi ipliklerle dokunmuştur (Foto 8).

Örnek 9: 18. yüzyıla tarihlenebilen Salur halısıdır. Yün iplikle, Türk düğüm tekniği kullanılarak dokunmuştur. Ebatları 145x176 cm. dir. Zeminde dört kollu göbek bulunmaktadır. Dört kollu göbeğin etrafı çengellerle çevrelenmiştir. Göbeğin iki ucunda birbirine paralel iki küçük göbek bulunmaktadır. Halıyı tarak motifli tek kuşak çevreler. Halının alt ve üst kenarlarında ki şeritlerde ev desenleri görülmektedir. Halı çivit mavisi, kırmızı, beyaz, kahverengi, pembe, açık sarı, ve siyah renkli ipliklerle dokunmuştur (Foto 9).

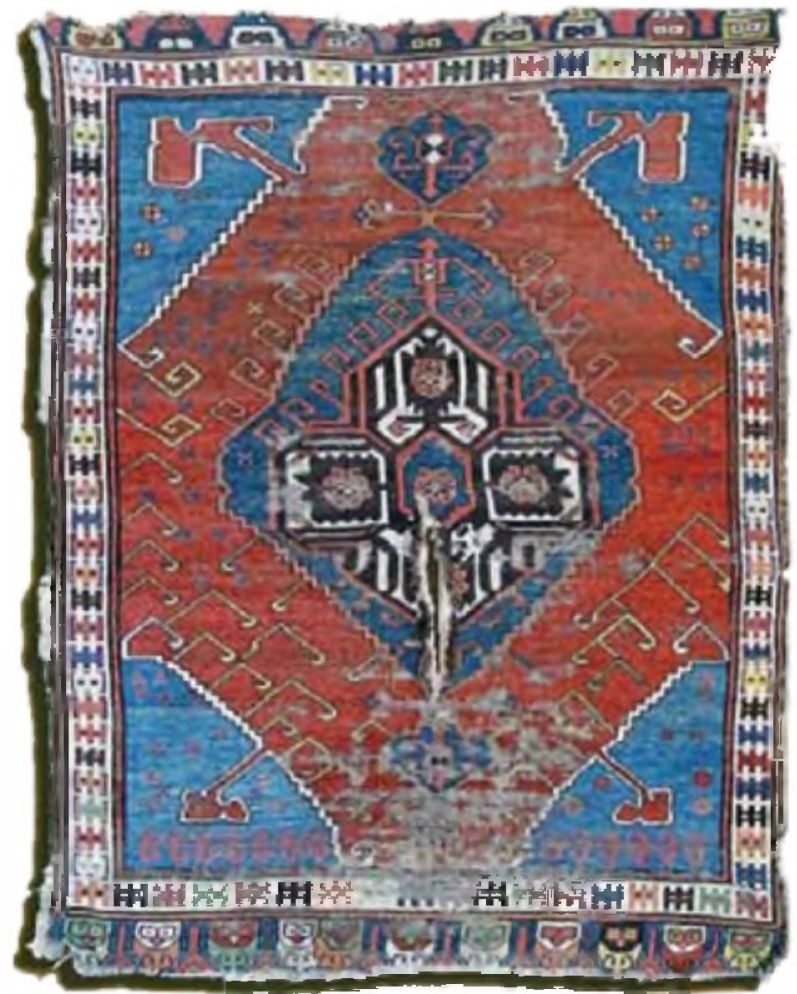

Foto 8 
Örnek 10: 18. yüzyıla tarihlenebilen Salur halısıdır. Yün iplikle, Türk düğüm tekniği kullanılarak dokunmuştur. Ebatları 146xl73 cm. dir. Zeminde dört kollu göbek bulunmaktadır. Göbeğin iki ucunda birbirine paralel iki küçük göbek bulunmaktadır. Bu göbekler elibelinde motifi ile nihayetlenmektedir. Halıyı akrep motifini andıran şekillerle süslenmiş ince bir kuşak çevrelemektedir. Halının alt ve üst kenarlarında ki şeritlerde ev desenleri görülmektedir. Halı çivit mavisi, açık mavi, kırmızı, beyaz, kahverengi, pembe, açık sarı ve siyah renkli ipliklerle dokunmuştur (Foto 10).

Örnek 11: Yarım bir halı parçasıdır. 18. yüzyıla tarihlenebilen Karapınar halısı yün iplikle, Türk düğüm tekniği kullanılarak dokunmuştur. Ebatları 100x120 $\mathrm{cm}$. dir. Zeminde büyükçe bir göbek bulunmaktadır. Göbeğin etrafı, farklı renkler kullanılarak oluşturulmuş şeritlerle çevrelenmiştir. Halıyı çevreleyen ince kuşak, yıldız şekilli çiçek motifleri ile süslenmiştir. Halı çivit mavisi, açık mavi, kırmızı, beyaz, yeşil, siyah ve turuncu renkli ipliklerle dokunmuştur (Foto 11).

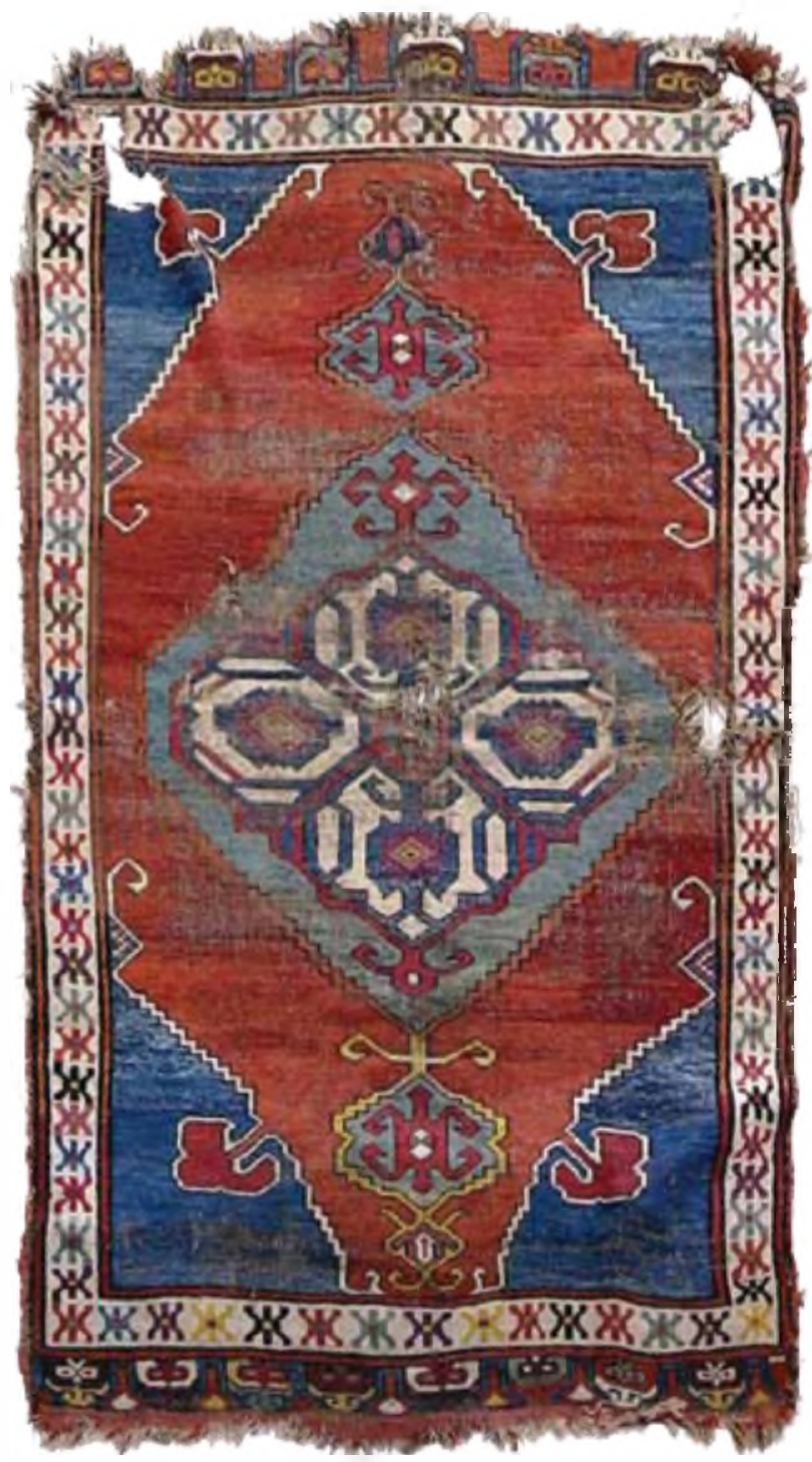

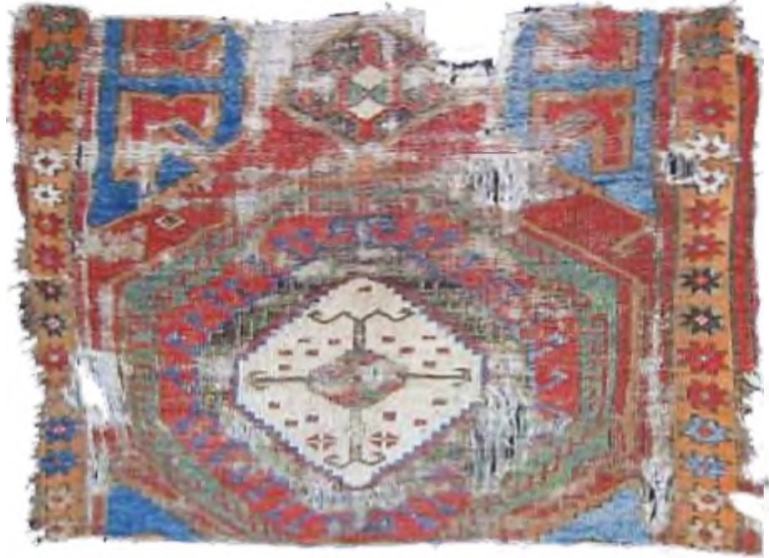

Foto 11

Örnek 12: Halıda yer yer sökülmeler görülmektedir. 18. yüzyıla tarihlenebilen Salur halısıdır. Yün iplikle, Türk düğüm tekniği kullanılarak dokunmuştur. Ebatları 128x178 cm. dir. Zeminde dört kollu göbek bulunmaktadır. Göbeğin iki ucunda birbirine paralel iki küçük göbek vardır ve bu göbekler elibelinde motifi ile nihayetlenmektedir. Halıyı stilize çiçek motifli ince bir kuşak çevrelemektedir. Halının alt ve üst kenarlarında ki şeritlerde ev desenleri görülmektedir. Halı çivit mavisi, açık mavi, kırmızı, beyaz, kahverengi, açık sarı ve siyah renkli ipliklerle dokunmuştur (Foto 12).

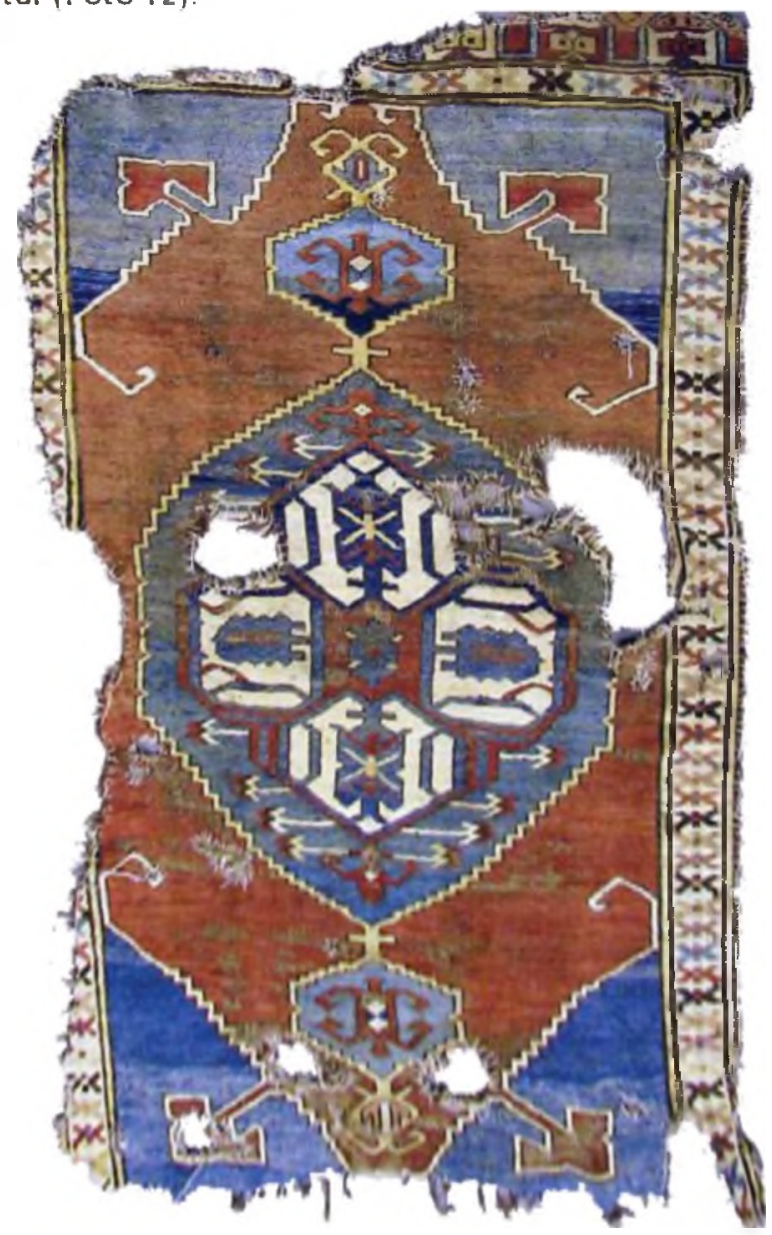

Foto 12 
Örnek 13: Üç göbekli tipik 18. yüzyıla tarihlenebilen Karapınar Salur halısıdır. Yün iplikle, Türk düğüm tekniği kullanılarak dokunmuştur. Ebatları 135x375 $\mathrm{cm}$. dir. Zeminde dört kollu göbek bulunmaktadır. Dört kollu göbeğin etrafı çengellerle çevrelenmiştir. Zeminde görülen üç büyük göbek birbirine küçük göbeklerle bağlanmıştır. Halıyı tarak motifli tek kuşak çevrelemektedir. Halı çivit mavisi, kırmızı, beyaz, yeşil, mor ve sarı renkli ipliklerle dokunmuştur (Foto 13).

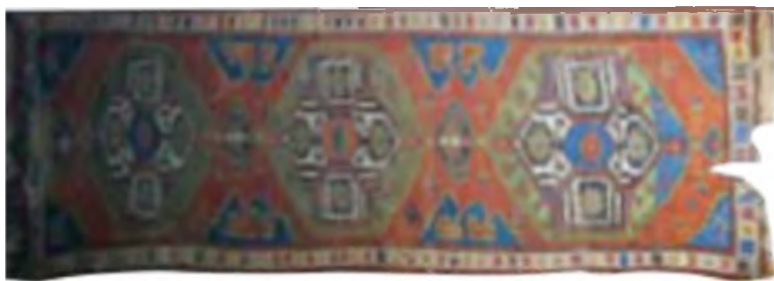

Foto 13

Örnek 14: 19. yüzyıla tarihlenebilen Karapınar Salur halısıdır. Yün iplikle, Türk düğüm tekniği kullanılarak dokunmuştur. Ebatları 145x210 cm. dir. Zeminde dört kollu göbek bulunmaktadır. Göbeğin iki ucunda birbirine paralel iki küçük göbek vardır ve bu göbekler elibelinde motifi ile nihayetlenmektedir. Göbeğin etrafında, eşkenar dörtgen şekillerin içerisine yerleştirilmiş yıldızlar dikkati çekmektedir. Halıyı, küçük çiçek motifleri ile süslü ince bir iç kuşak ve hançer şekilli yapraklarla süslü geniş bir dış kuşak çevrelemektedir. Halı mavi, bordo, turuncu, yeşil, mor, siyah ve beyaz renkli ipliklerle dokunmuştur (Foto 14).

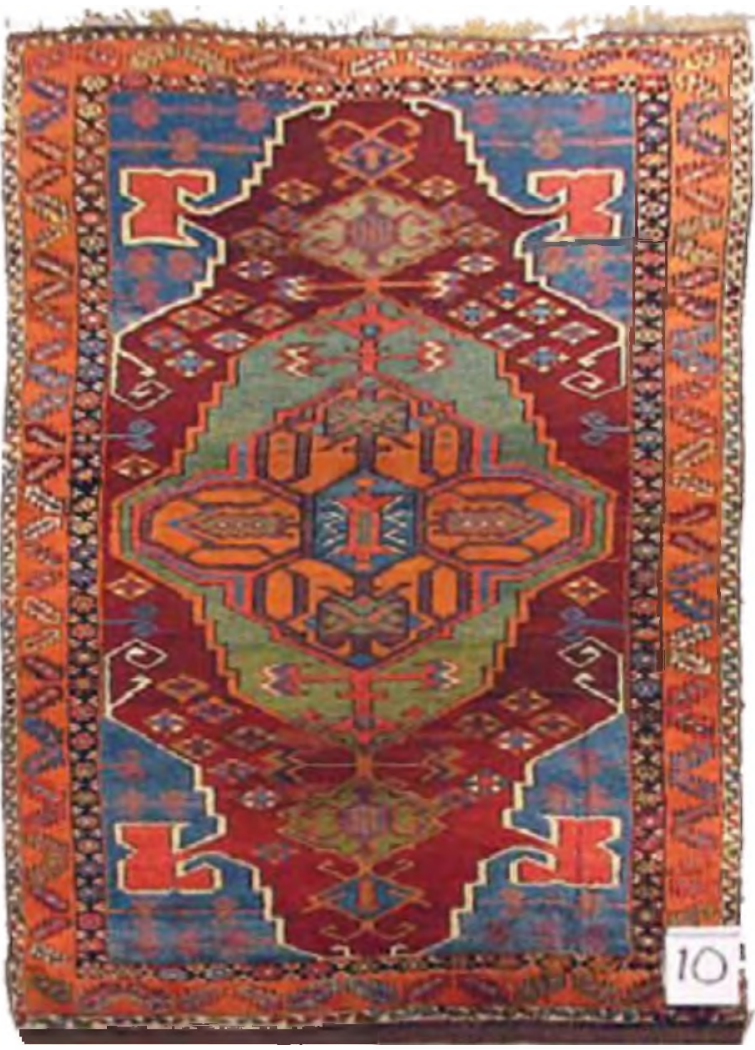

Foto 14
Örnek 15: 19. yüzyıla tarihlenebilen Karapınar Salur halısıdır. Yün iplikle, Türk düğüm tekniği kullanılarak dokunmuştur. Ebatları $140 \times 176 \mathrm{~cm}$. dir. Zeminde dört kollu göbek bulunmaktadır. Göbeğin etrafını çengeller çevreler. Göbeğin iki ucunda birbirine paralel iki küçük göbek vardır. Halıyı tarak motifli tek kuşak çevrelemektedir. Halının alt ve üst kenarlarında ki şeritte ev desenleri görülüyor. Halı mavi, kırmızı, sarı, yeşil, mor, beyaz ve kahverengi ipliklerle dokunmuştur (Foto 15).

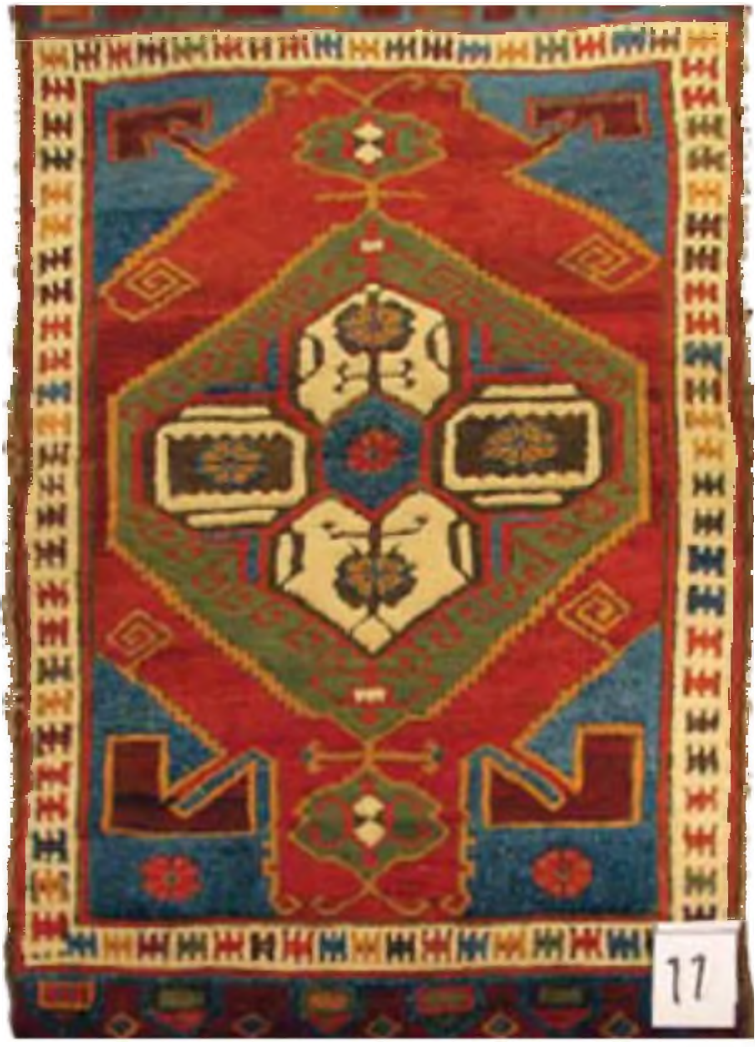

Foto 15 .

Örnek 16: Üç göbekli tipik 19. yüzyıla tarihlenebilen Karapınar Salur halısıdır. Yün iplikle, Türk düğüm tekniği kullanılarak dokunmuştur. Ebatları $128 \times 425 \mathrm{~cm}$. dir. Zeminde dört kollu göbek bulunmaktadır. Dört kollu göbeğin etrafı çengellerle çevrelenmiştir. Zeminde görülen üç büyük göbek birbirine küçük göbeklerle bağlanmıştır. Halıyı tarak motifli tek kuşak çevrelemektedir. Halının alt ve üst kenarlarında ki şeritte ev desenleri görülmektedir. Halı mavi, bordo, beyaz, siyah ve pembe renkli ipliklerle dokunmuştur (Foto 16).

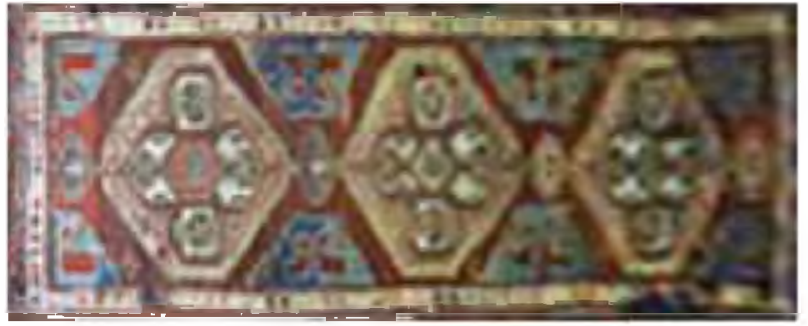

Foto 16 . 
Örnek 17: 19. yüzyıla tarihlenebilen Karapınar Salur halısıdır. Yün iplikle, Türk düğüm tekniği kullanılarak dokunmuştur. Ebatları 138x176 cm. dir. Zeminde eşkenar dörtgen biçiminde, dört kollu bir göbek bulunmaktadır. Göbeğin her iki ucunda birer küçük göbek ile bu göbeklere bitişik birer eşkenar dörtgen görülüyor ve eşkenar dörtgenler elibelinde motifi ile nihayetleniyor. Zeminin köşelerinde balık kılçı̆̆ını andıran süslemeler dikkati çeker. Halıyı tarak motifli tek bir kuşak çevrelemektedir. Halının alt ve üst kenarlarında ki şeritlerde ev desenleri görülmektedir. Halı mavi, bordo, beyaz, siyah ve pembe renkli ipliklerle dokunmuştur (Foto 17).

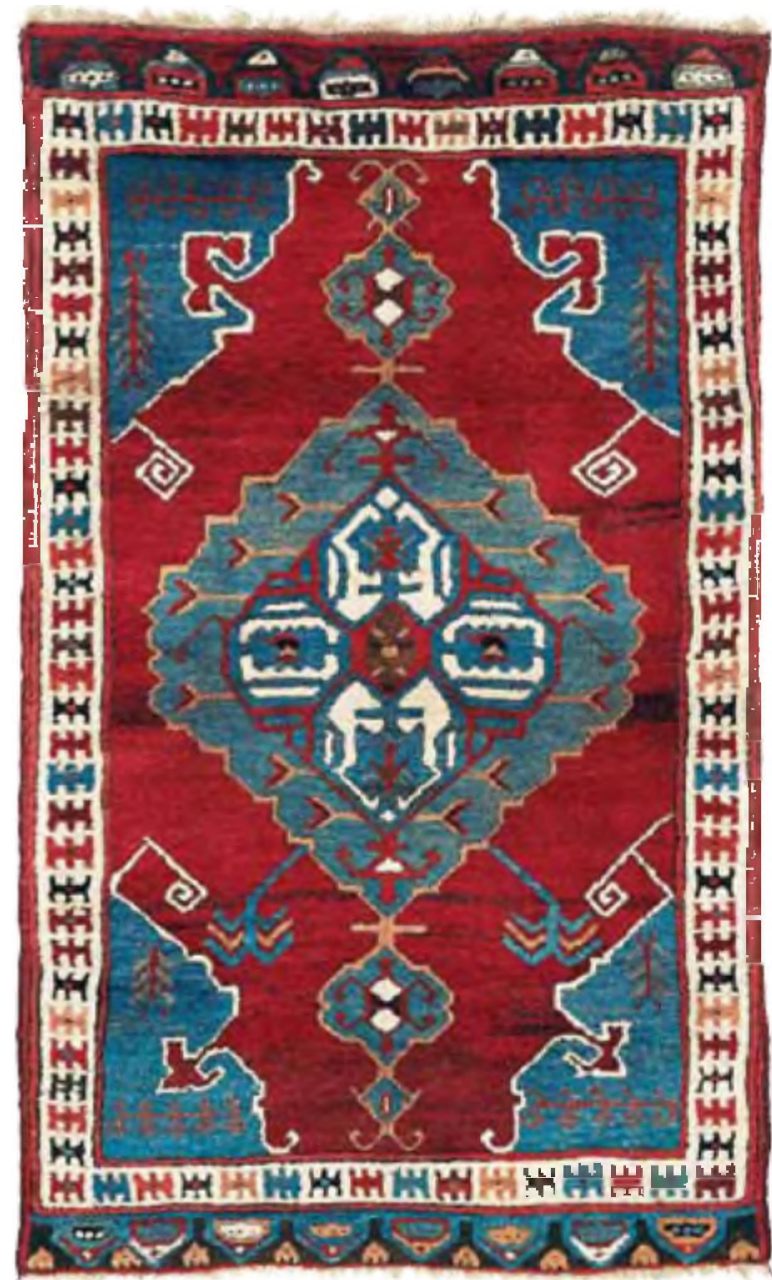

Foto 17

Örnek 18: Üç göbekli tipik 19. yüzyıla tarihlenebilen Karapınar Salur halısıdır. Yün iplikle, Türk düğüm tekniği kullanılarak dokunmuştur. Ebatları $138 \times 410 \mathrm{~cm}$. dir. Zeminde dört kollu göbek bulunmaktadır. Dört kollu göbeğin etrafı çengellerle çevrelenmiştir. Zeminde görülen üç büyük göbek birbirine küçük göbeklerle bağlanmıştır. Halıyı tarak motifli tek kuşak çevrelemektedir. Halının alt ve üst kenarlarında ki şeritlerde ev desenleri görülmektedir. Halı çivit mavisi, açı mavi, kırmızı, beyaz ve siyah renkli ipliklerle dokunmuştur (Foto 18).

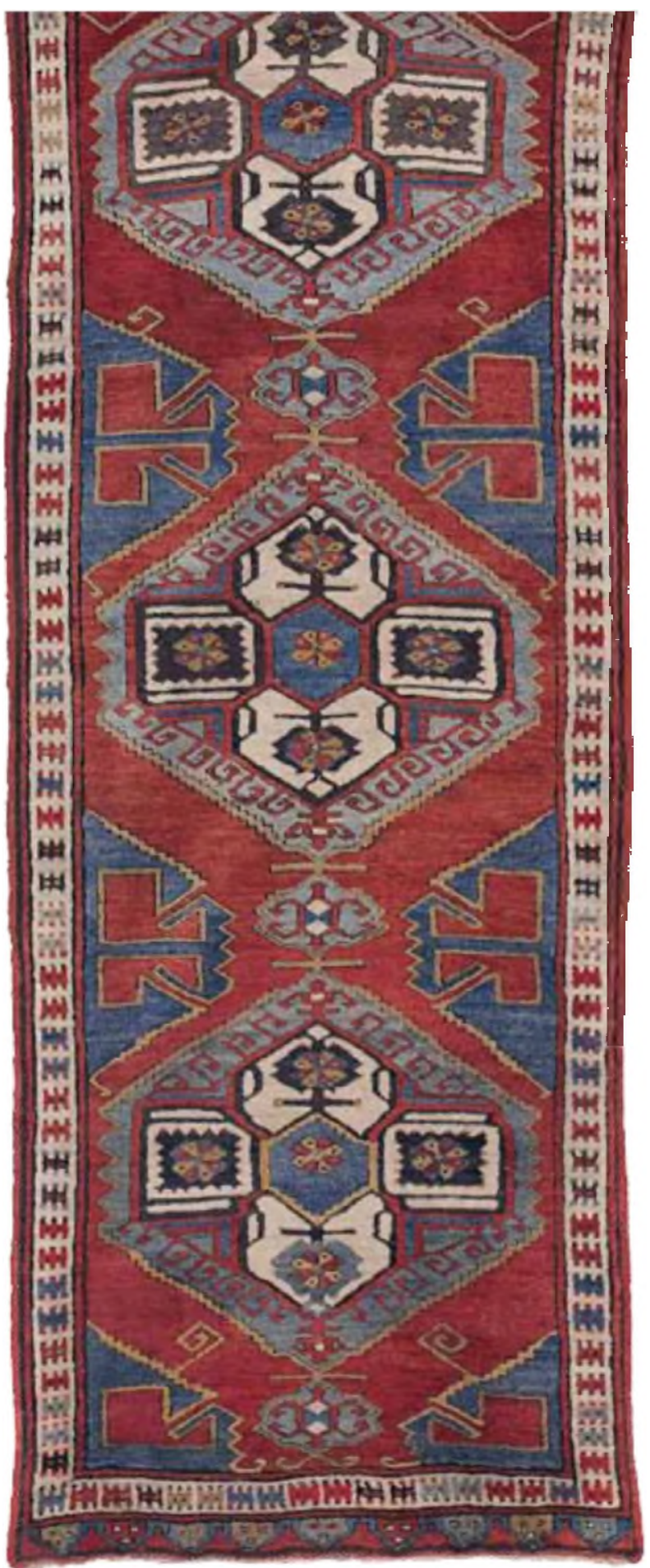

Foto 18

Örnek 19: 19. yüzyıla tarihlenebilen Karapınar Salur halısıdır. Yün iplikle, Türk düğüm tekniği kullanılarak dokunmuştur. Ebatları 135x168 cm. dir. Zeminde dört kollu göbek bulunmaktadır. Dört kollu göbeğin etrafını çengeller çevrelemektedir. Göbeğin iki ucunda birbirine paralel iki küçük göbek, elibelinde motifi ile nihayetlenmektedir. Halıyı stilize çıçek motifli tek kuşak çevrelemektedir. Halının alt ve üst kenarlarında ki şeritte bozulmuş ev desenleri görülmektedir. Halı mavi, vişne rengi, sarı, yeşil, beyaz ve kahverengi ipliklerle dokunmuştur (Foto 19). 


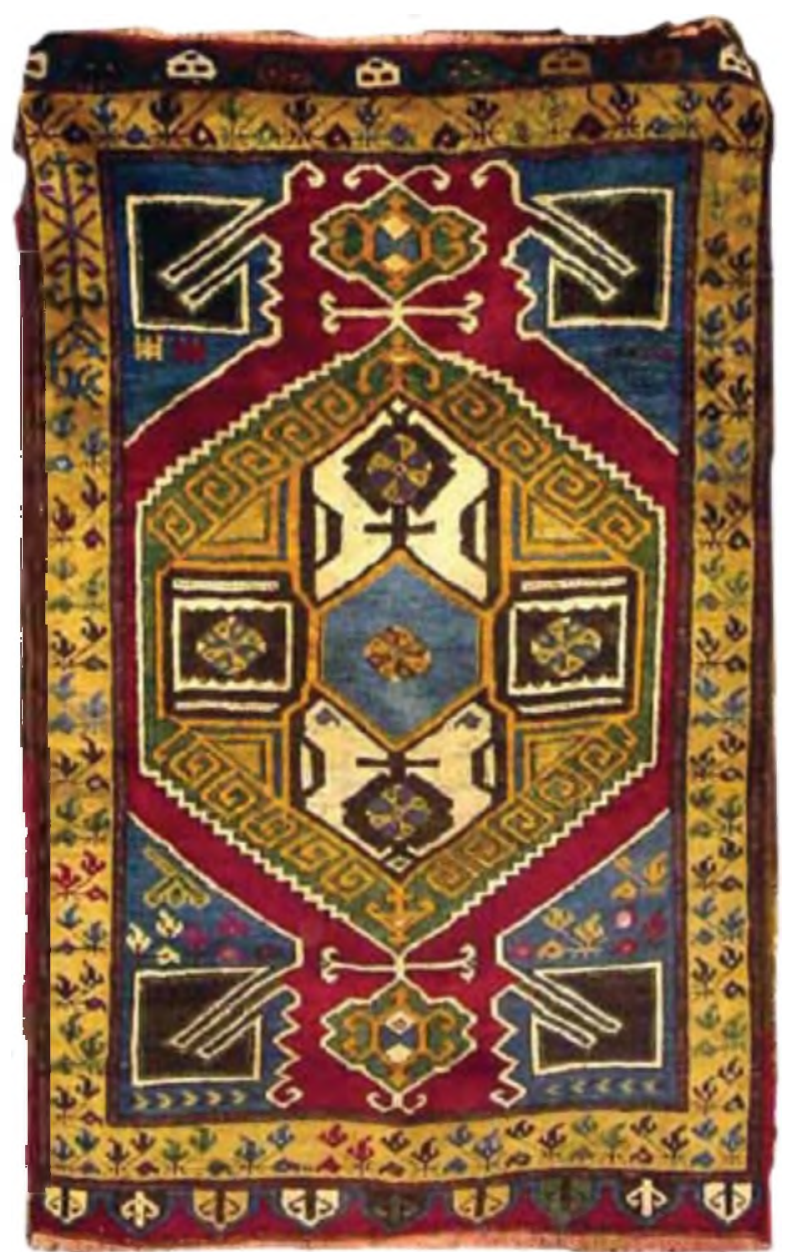

Foto 19

Örnek 20: 19. yüzyıla tarihlenebilen Karapınar Salur halısıdır. Yün iplikle, Türk düğüm tekniği kullanılarak dokunmuştur. Ebatları $145 \times 172 \mathrm{~cm}$. dir. Zeminde dört kollu göbek bulunmaktadır. Dört kollu göbeğin etrafını çengeller çevrelemektedir. Göbeğin iki ucunda birbirine paralel iki küçük göbek, elibelinde motifi ile nihayetlenmektedir. Halıyı geometrik desenli tek bir kuşak çevrelemektedir. Halının alt ve üst kenarlarında ki şeritte ev desenleri görülmektedir. Halı mavi, kırmızı, sarı, turuncu, krem rengi ve beyaz renkli ipliklerle dokunmuştur (Foto 20).

Örnek 21: 19. yüzyıla tarihlenebilen Karapınar halısıdır. Yün iplikle, Türk düğüm tekniği kullanılarak dokunmuştur. Ebatları $110 \times 145 \mathrm{~cm}$. dir. Zeminde bir sekizgen görülmektedir. Sekizgenin iç ve dış çeperi küçük üçgenlerle çevrelenmiş olup, merkezinde birbirine paralel, bozulmuş koçbaşı motifi görülmektedir. Zeminde görülen sekizgen şekilli motifin her iki ucunda birer küçük göbek görülür. Bu göbekler elibelinde motifi ile sonlanmaktadır. Halıyı tarak motifli tek bir kuşak çevreler. Halının alt ve üst kenarlarında ki şeritte ev desenleri görülmektedir. Halı bordo, mavi, açık kahverengi ve beyaz renkli ipliklerle dokunmuştur (Foto 21).

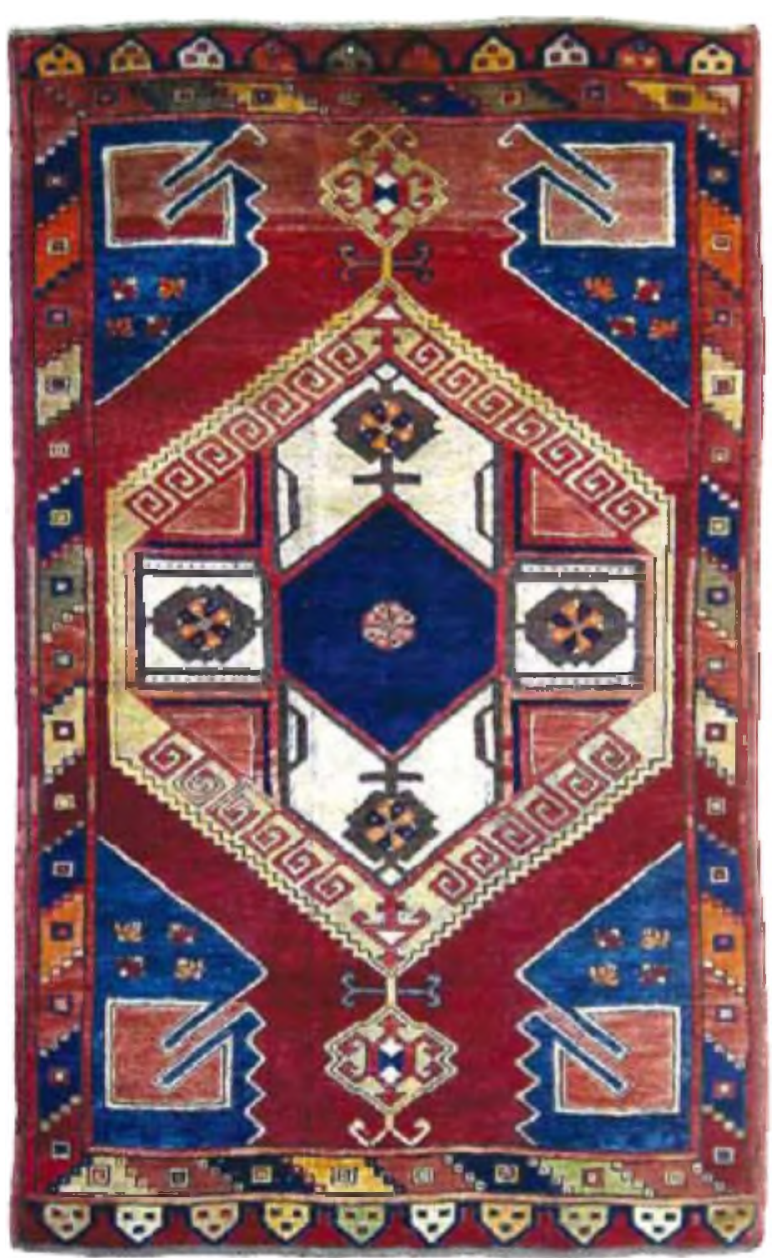

Foto 20

Örnek 22: 19. yüzyıla tarihlenebilen Karapınar Salur halısıdır. Yün iplikle, Türk düğüm tekniği kullanılarak dokunmuştur. Ebatları $120 \times 160 \mathrm{~cm}$. dir. Zeminde dört kollu göbek bulunmaktadır. Dört kollu göbeğin etrafını çengeller çevrelemektedir. Göbeğin iki ucunda birbirine paralel iki küçük göbek, elibelinde motifi ile nihayetlenmektedir. Halıyı tarak motifli tek kuşak çevrelemektedir. Halının alt ve üst kenarlarında ki şeritte ev desenleri görülmektedir. Halı mavi, kırmızı, mor, krem ve beyaz renkli ipliklerle dokunmuştur (Foto 22).

Örnek 23: 19. yüzyıla tarihlenebilen Karapınar Salur halısıdır. Yün iplikle, Türk düğüm tekniği kullanılarak dokunmuştur. Ebatları $125 \times 165 \mathrm{~cm}$. dir. Zeminde dört kollu göbek bulunmaktadır. Dört kollu göbeğin etrafını çengeller çevrelemektedir. Göbeğin her iki ucunda birbirine paralel iki küçük göbek görülür. Halıyı tarak motifli tek kuşak çevrelemektedir. Halı vişne rengi, mavi, yeşil, sarı ve beyaz renkli ipliklerle dokunmuştur (Foto 23).

Örnek 24: 19. yüzyıla tarihlenebilen Karapınar Salur halısıdır. Yün iplikle, Türk düğüm tekniği kullanılarak dokunmuştur. Ebatları 146xl66 cm. dir. Zeminde dört kollu göbek bulunmaktadır. Dört kollu göbeğin etrafını çengeller çevrelemektedir. Göbeğin 


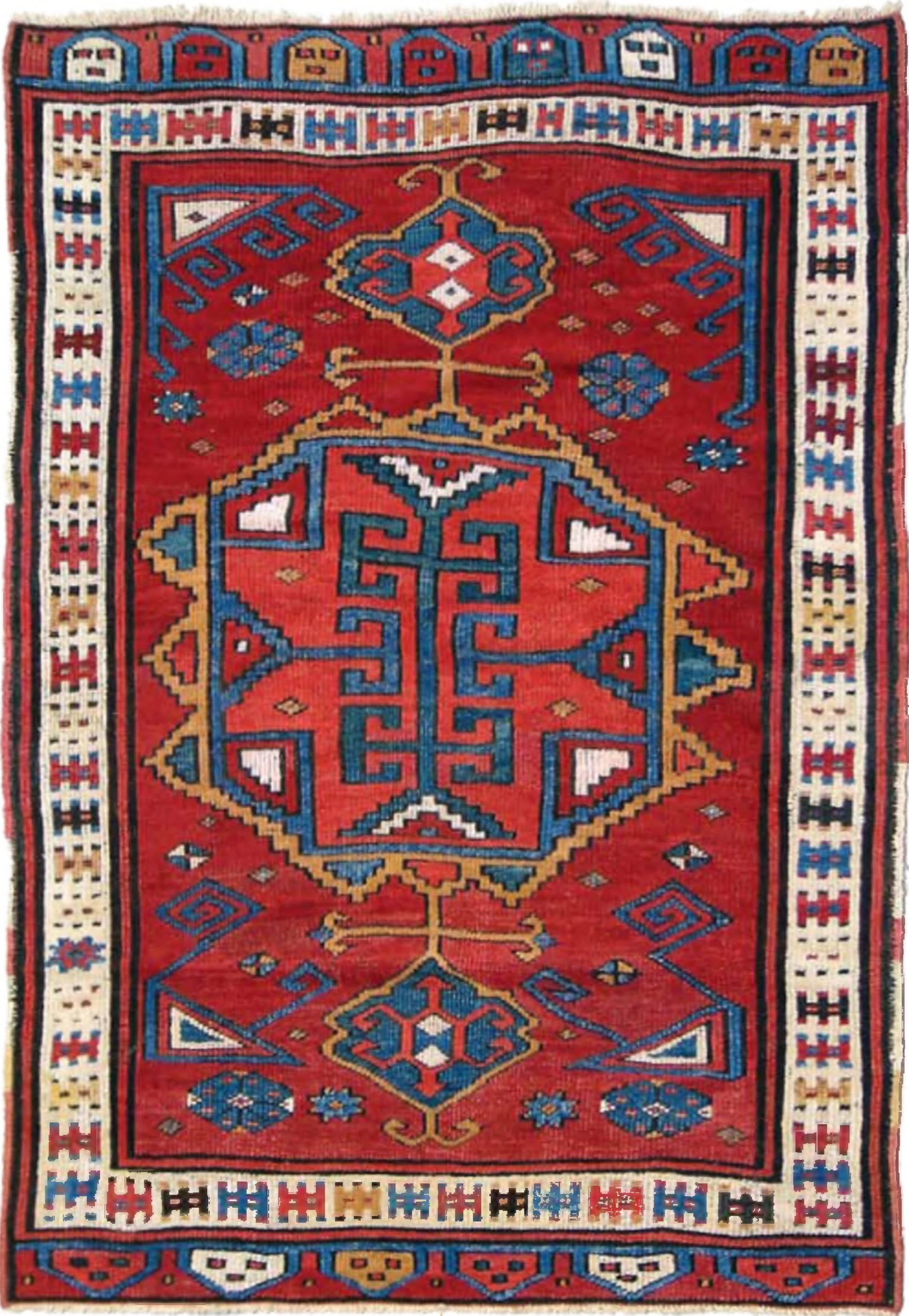



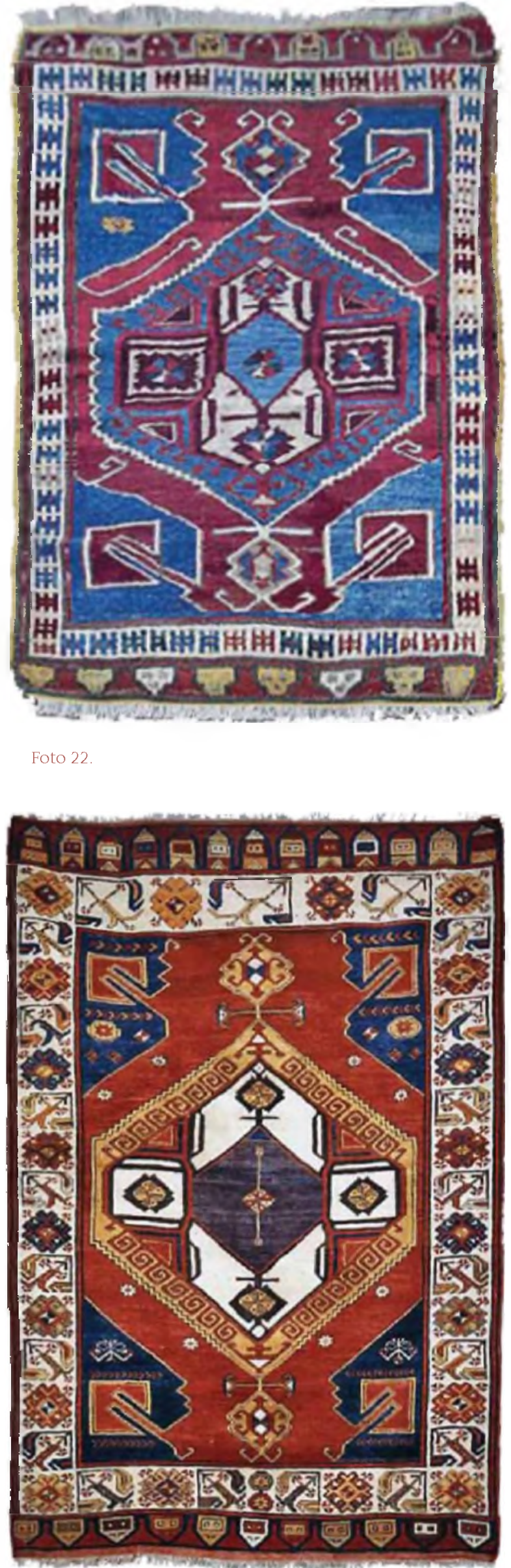

Foto 24

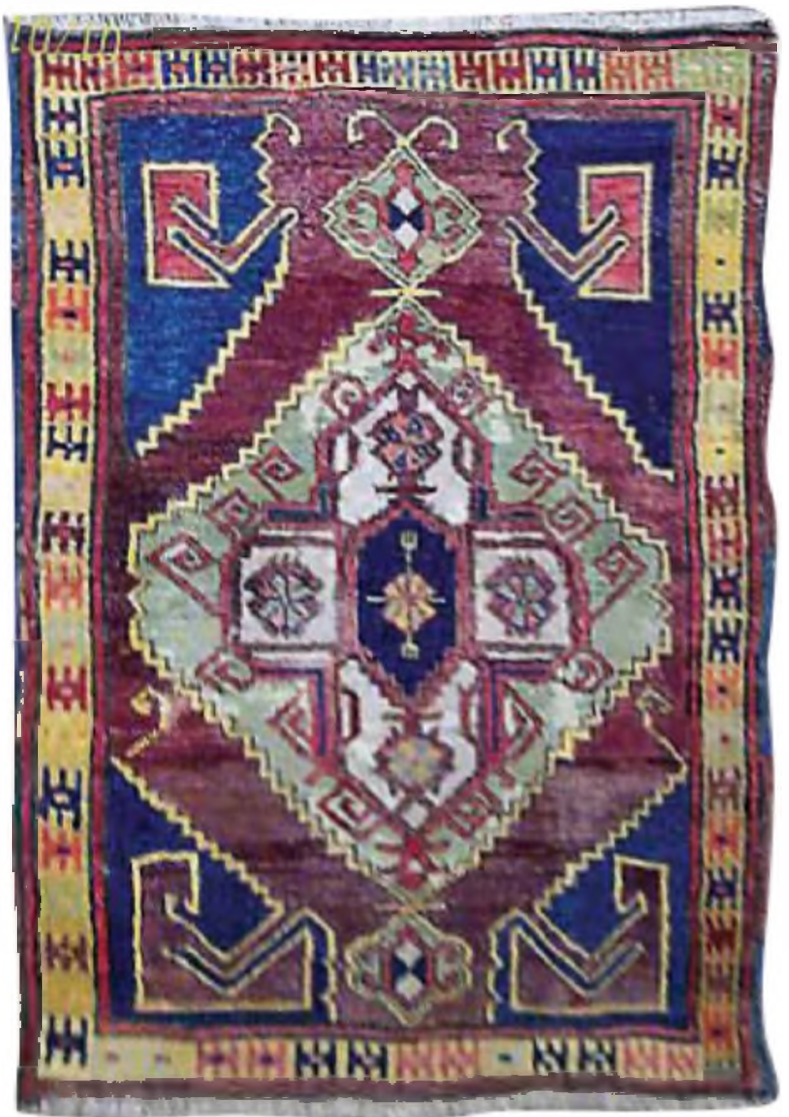

Foto 23

iki ucunda birbirine paralel iki küçük göbek, elibelinde motifi ile nihayetlenmektedir. Zemin köşelerinde başak motifini andıran süslemeler dikkati çeker. Halıyı tek kuşak çevrelemektedir. Bu kuşakta, Lâdik halılarında görülen, lale ve karanfilin birbiri ardınca işlendiği ve "Lâdik gülü" olarak adlandırılan motifin işlendiği görülmektedir. Halının alt ve üst kenarlarında ki şeritlerde ev desenleri görülmektedir. Halı kırmızı, mavi, krem, koyu sarı, mor ve beyaz renkli ipliklerle dokunmuştur (Foto 24).

Örnek 25: 19. yüzyıla tarihlenebilen Karapınar Salur halısıdır. Yün iplikle, Türk düğüm tekniği kullanılarak dokunmuştur. Ebatları $111 \times 165 \mathrm{~cm}$. dir. Zeminde dört kollu göbek bulunmaktadır. Dört kollu göbeğin etrafını çengeller çevrelemektedir. Göbeğin iki ucunda birbirine paralel iki küçük göbek, elibelinde motifi ile nihayetlenmektedir. Halıyı yıldız şekilli çiçek motiflerinin işlendiği tek bir kuşak çevrelemektedir. Halının alt ve üst kenarlarında ki șeritlerde ev desenleri görülmektedir. Halı mavi, krem, beyaz, bordo, sarı, mor ve kahverengi ipliklerle dokunmuştur (Foto 25).

Örnek 26: 19. yüzyıla tarihlenebilen Karapınar Salur halısıdır. Yün iplikle, Türk düğüm tekniği kullanılarak dokunmuştur. Ebatları 145x165 cm. dir. Zeminde dört kollu göbek bulunmaktadır. Dört kollu göbeğin etrafını çengeller çevrelemektedir. Göbe- 


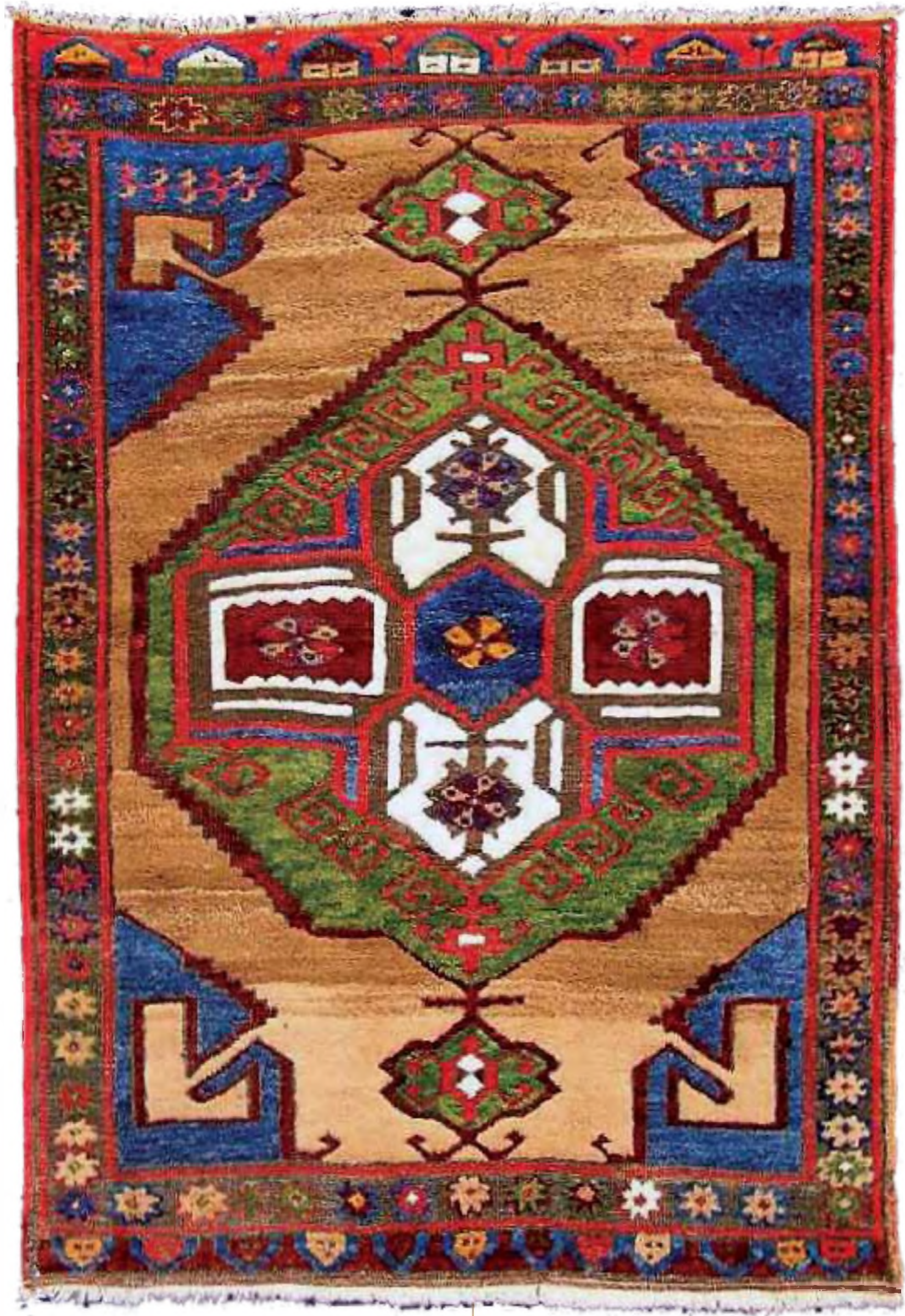




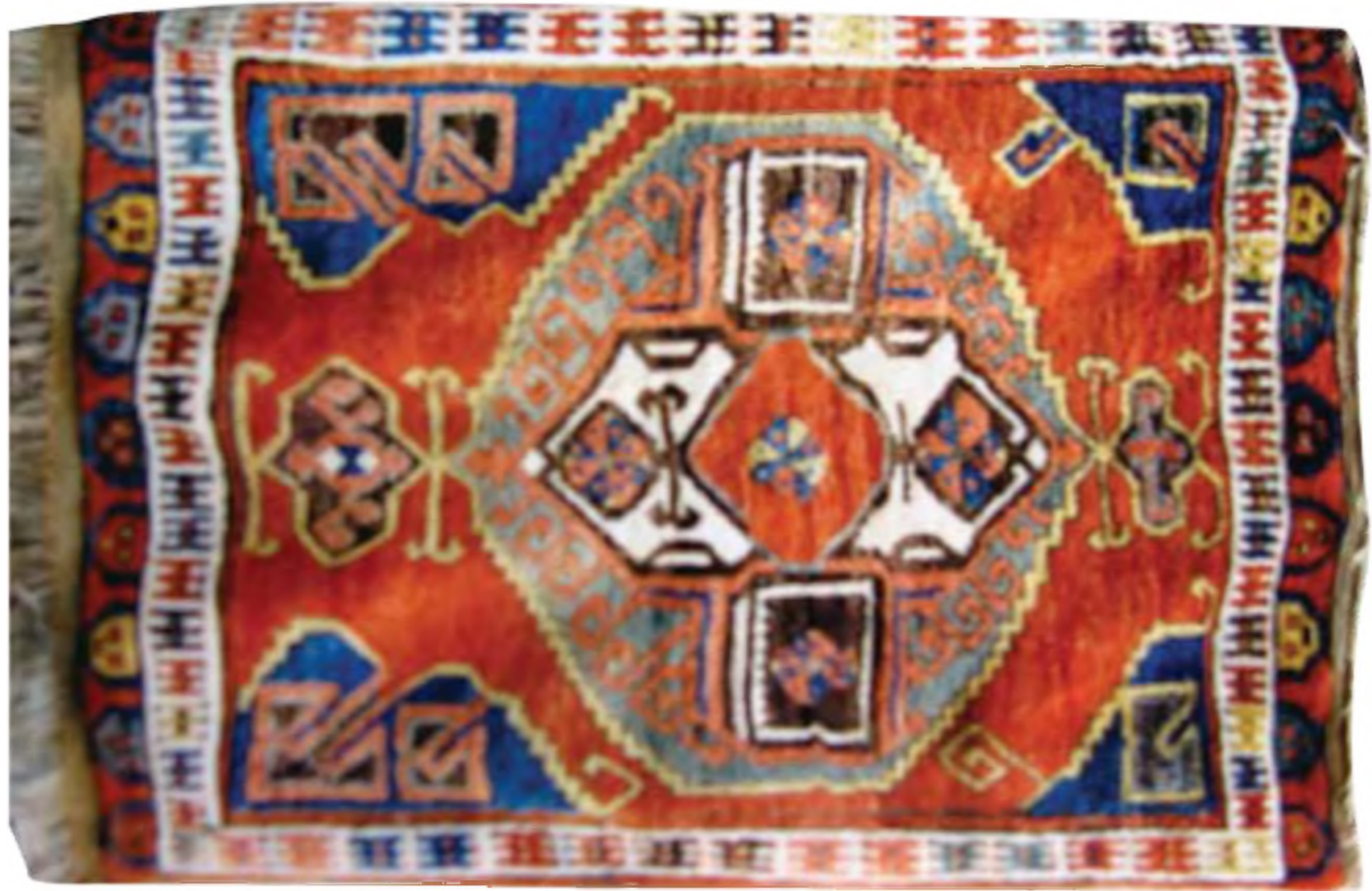

Foto 26
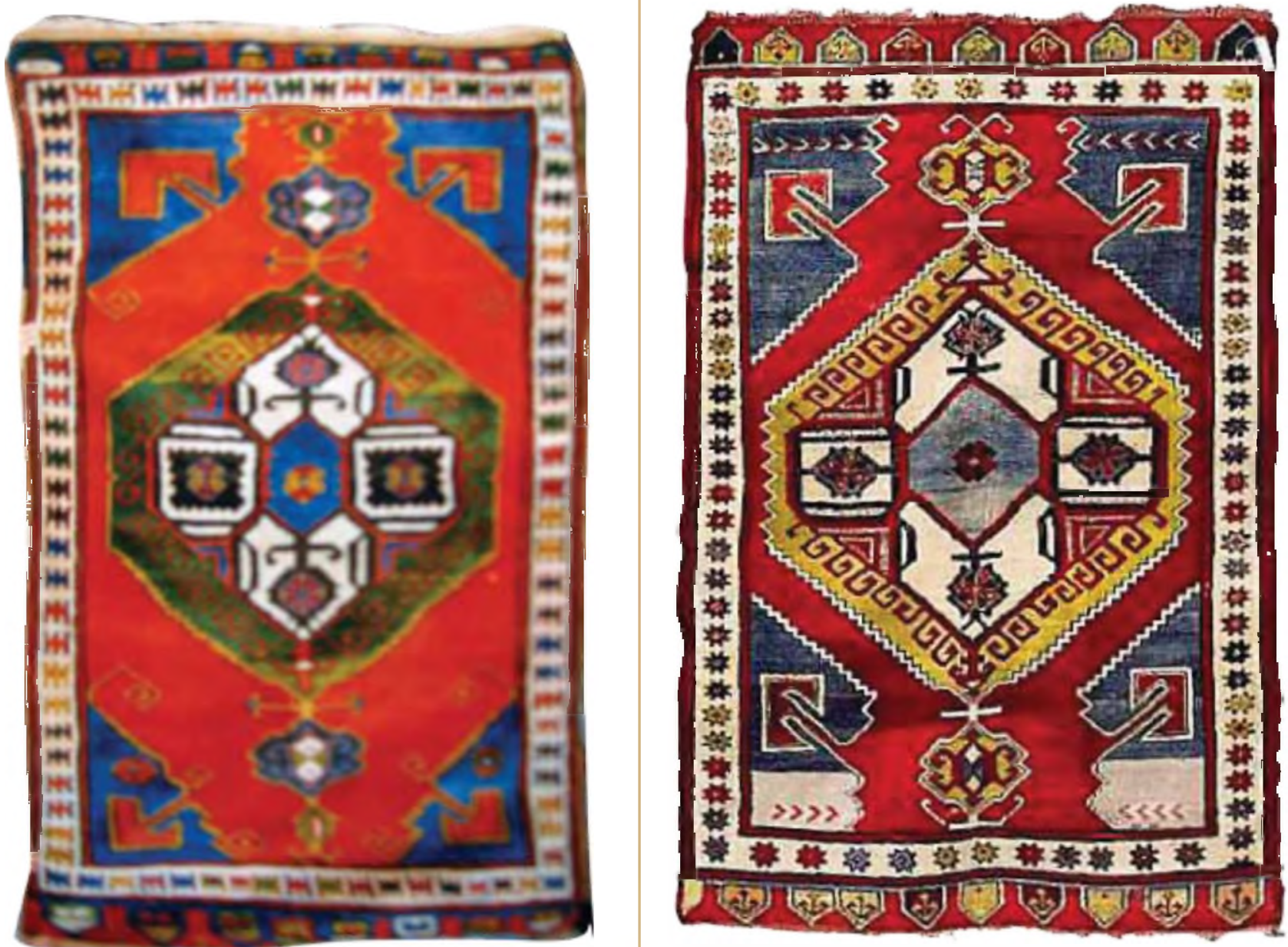
ğin iki ucunda birbirine paralel iki küçük göbek bulunuyor. Halıyı tarak motiflerinin işlendiği tek bir kuşak çevrelemektedir. Halının alt ve üst kenarlarında ki şeritte ev desenleri görülmektedir. Halı mavi, turuncu, beyaz, kahverengi ve gri renkli ipliklerle dokunmuştur (Foto 26).

Örnek 27: 19. yüzyıla tarihlenebilen Karapınar Salur halısıdır. Yün iplikle, Türk düğüm tekniği kullanılarak dokunmuştur. Ebatları $140 \times 180 \mathrm{~cm}$. dir. Zeminde dört kollu göbek bulunmaktadır. Dört kollu göbeğin etrafını çengeller çevrelemektedir. Göbeğin iki ucunda birbirine paralel iki küçük göbek bulunuyor. Halıyı tarak motiflerinin işlendiği tek bir kuşak çevrelemektedir. Halının alt ve üst kenarlarında ki şeritte ev desenleri görülmektedir. Halı mavi, turuncu, yeşil, beyaz ve sarı renkli ipliklerle dokunmuştur (Foto 27).

Örnek 28: 19. yüzyıla tarihlenebilen Karapınar Salur halısıdır. Yün iplikle, Türk düğüm tekniği kullanılarak dokunmuştur. Ebatları 135x165 cm. dir. Zeminde dört kollu göbek bulunmaktadır. Dört kollu göbeğin etrafını çengeller çevrelemektedir. Göbeğin iki ucunda birbirine paralel iki küçük göbek bulunuyor. Bu göbeklerden biri elibelinde motifi ile sonlanıyor. Zemin köşelerinde başak motifini andıran süslemeler dikkati çeker. Halıyı yıldız şekilli çiçek motiflerinin işlendiği tek bir kuşak çevrelemektedir. Halının alt ve üst kenarlarında ki şeritte ev desenleri görülmektedir. Halı mavi, bordo, beyaz ve sarı renkli ipliklerle dokunmuştur (Foto 28).

\section{Değerlendirme}

“Karapınar (Konya) Yöresi Göbekli Karapınar Halıları" isimli çalışmamızda, Karapınar yöresine ait 28 adet halı incelenmiştir. Araştırmamız neticesinde 28 adet halıdan 25 tanesinin Karapınar'ın Salur köyünde dokunmuş, Salur modeli olarak bilinen eserler olduğu tespit edilmiştir(Örnek no: 1-5, 7-10, 12-20, 2228). ${ }^{12}$ İncelediğimiz eserlerin 13 tanesi 18. yüzyıl (Örnek no: 1-131, 15 tanesi ise 19. yüzylla tarihleyebileceğimiz (Örnek no: 14-28) örneklerdir. İncelenen halıların tamamı yün iplik kullanılarak Türk düğüm tekniği ile dokunmuştur.

İncelediğimiz 28 adet eseri, kullanılan renklere göre değerlendirdiğimizde, beyaz rengin tüm halılarda kullanıldığı görülmektedir. Beyaz renkten sonra en çok kullanılan renkler, kırmızı, mavi, kahverengi, sarı ve yeşildir. Ayrıca siyah, çivit mavisi, pembe, krem, mor, turuncu, bordo, vişne rengi ve gri renklerde halılarımızda kullanılmıştır. İncelediğimiz Göbek-

12 Halılara ait örnek numaraları ile fotoğraf numaraları aynı takip ettiği için metin içinde sadece "örnek no" olarak verilmiştir. li Karapınar halılarında en dikkat çeken renkler çivit mavisi ve kırmızıdır. Bu iki renk 18. yüzyıla tarihleyebileceğimiz halılarında yaygın olarak kullanılmış, 19. yüzyılda ise değişikliğe maruz kalmıştır. 19. yüzyıla tarihleyebileceğimiz örneklerde çivit mavisi yerine mavi, kırmızı yerine ise kırmızıya yakın tonların tercih edildiği görülmektedir.

İncelediğimiz halıları, zeminde görülen kompozisyonları açısından değerlendirdiğimizde; yedi tanesinin zemininde dört kollu, birbirine küçük göbeklerle bağlı üç büyük göbek (Örnek no: $1,5,7,8,13,16,18$ ), 18 tanesinin zemininde ise dört kollu büyükçe bir göbek (Örnek no: 2-4, 9, 10,12,14,15,17,19,20,22-28) görülmektedir.

Anadolu halılarında göbek (madalyon), ilk defa 15. yüzyılın ikinci yarısında görülmeye başlamıştır. Aynı döneme tarihlenen İran minyatürlerinde madalyonlu halı tasvirlerine rastlanmaktadır. 16. yüzyıl İran halılarında madalyon şeması önemli rol oynar. Bu şema, yazma eserlerin tezhipli sayfalarında ve ciltleri üzerinde görülür. Halıya da buradan geçmiş olması muhtemeldir. ${ }^{13}$ Öyle ki zeminde bir ve üç göbeğin görüldüğü eserlerimizde, göbeğin zemine işlenişi, cilt sanatımızda, cildin üst kapağında görülen şemse-salbek düzenlemelerine benzerlik arz etmektedir.

İncelediğimiz halı örneklerinde, zeminlerinde yer alan göbek düzenlemelerinin ana hatlarıla iki ayrı tasarıma sahip olduğu görülür. Birinci grubunu, Salur modeli olarak bilinen örneklerdeki düzenleme, ikinci grubunu ise uç örnekten meydana gelen diğer halılar oluşturmaktadır(Örnek no: 6, 11, 21). Bu uç örnekte, Salur modeli halılardaki, göbeğin merkezinde açıkça seçilebilen "dört yön" veya dört kollu yıldızdan oluşan düzenleme görülmez. Bu halılardan birinde (Örnek no:6) sağlam kalabilen kısmından görüldüğü kadarıyla, zeminde bitkisel süslemenin hâkim olduğu büyükçe bir göbeğin yer aldı ̆̆ı anlaşılmaktadır. İkinci örnekte (Örnek no:11) göbekte iki ucu pahlanmış bir dörtgen ve dörtgenin etrafında, farklı renklerle oluşturulmuş üç sıra şerit görülmektedir. Bu detaylarla, zeminde büyükçe bir göbek varmış izlenimi kazanmıştır. Bu halıların üçüncü örneği (Örnek no:21) göbekte yer alan, eşit kenarlara sahip olmayan bir sekizgen ile sekizgenin içinde ve dişındaki geometrik motiflerle bezenmiştir.

İncelediğimiz 28 adet halıyı, kuşakları açısından değerlendirdiğimizde bir örneğimiz hariç (Örnek no: 14) tüm eserlerimizde tek kuşak görülmektedir. Tek kuşaklı halılarda en çok tarak motifi işlenmiştir. Ay-

13 Kurt Erdmann, Der Turkische Teppich Des 15. Jahrhunderts, (Çeviren: H. Taner, 15. Astr Türk Halısi), İstanbul, (basim tarihi yok), s. 108. 
rıca halının kısa kenarlarında mevcut olan ince şeritlerde yan yana dizilmiş küçük ev tasvirleri görülür (Örnek no: 2, 4, 8, 9, 13, 15, 16, 17, 18, 21, 22, 26, 27). 7 ve 23 numaralı örneklerde halıyı, tarak motifli tek bir kuşak çevrelemekle birlikte bu halılarının kısa kenarlarında şerit görülmemektedir. Kuşaklarında tarak motifi olan 1 ve 5 numaralı örneklerimizde ise halının kısa kenarlarında oluşan söküklerden dolayı ev tasvirlerinin olup olmadığı anlaşılamamaktadır.

Kuşaklarda görülen diğer bir bezeme ise yıldız şekilli çiçek motifleridir. Bu motif 11,25 ve 28 numaralı örneklerimizin kuşaklarında görülmektedir. 25 ve 28 numaralı örneklerimizde halının kısa kenarlarında ev tasvirinin işlendiği ince şerit bulunurken, 11 numaralı örneğimizin kısa kenarlarının yırtılmış olmasından dolayı ev tasvirinin işlenip işlenmediğini bilemiyoruz.

Tek kuşaklı halılar içerisinde iki örnekte kuşak genişliklerinin diğerlerine oranla çok daha geniş tutulduğu göze çarpar(Örnek no: 6, 24). 6 numaralı örneğimizin kuşağında, zikzak şekilli süslemenin bir altt-na bir üstüne işlenen stilize çiçek motifi, 24 numaralı örneğimizin geniş kuşağında Lâdik gülü deseni ve halının kısa kenarlarındaki dar şeritlerde ev tasviri görülmektedir.

10 numaralı örneğimizin kuşağında akrep figürünü andıran bir süsleme ve halının kısa kenarlarında bulunan ince şeride işlenmiş ev tasviri görülür. 12 ve 19 numaralı örneklerimizin kuşaklarında stilize çiçek motifleri yer alırken, 19 numaralı halının kısa kenarlarında bulunan ince şeritlerde ev tasviri işlenmiştir. 20 numaralı örnekte ise kuşakta geometrik desenler, kısa kenarlarında görülen ince şeritlerde ev tasviri yer almaktadır.

Eserlerimiz arasında iki kuşaklı olan örneğimizin (Örnek no: 14), zeminini çevreleyen dar kuşağında küçük çiçek motifleri, geniş kuşağında ise hançer şekilli yapraklar görülmektedir.

Çalışmamızda incelediğimiz halılar 18. ve 19. yüzyıllara tarihleyebileceğimiz örneklerdir. Bu halılarda görülen kompozisyona genel olarak baktığımızda, 19. yüzyıla ait örneklerde değişen özelliklerin sadece kullanılan renkler açısından olmadı̆̆ı anlaşılmaktadır. 19. yüzyıl göbekli Karapınar halılarında zeminde uygulanan kompozisyonun ana hatlarında bir değişme olmazken, sadelikten uzaklaşma görülür. Göbek ve kuşaklarında motiflerin kalabalıklaştığı, yeni motiflerin ortaya çıktığı göze çarpar. Örneğin 24 numaralı halının kuşağında görülen Lâdik gülü, Lâdik halılarına özgü bir desendir. Bu durumun sebebini Anadolu'da kendi zevk ve ihtiyaçlarına göre halı dokutan Avrupalı halı tüccarlarına bağlamak yanlış olmayacaktır.

\section{Sonuç}

Orta Anadolu halı dokuma merkezleri içinde Karapınar önemli bir yere sahiptir. Yününü kendi beslediği hayvanından elde eden, ipliğini doğal boyalarla renklendiren, dokumalarına kendi motiflerini işleyen Karapınarlı halı dokuyucular, eşsiz halı örnekleri üretmişlerdir. Bilinen en eski Karapınar halısı 17. yüzyıla aittir. Makalemizde ele aldığımız halılar ise 18 ve 19. yüzyıllara tarihleyebileceğimiz Göbekli Karapınar halılarıdır. Bu halılarda, zeminde büyükçe bir göbek ya da zeminde peş peşe işlenmiş üç göbek görülmektedir. Zeminin etrafı çoğunlukla tarak motifinin işlendiği tek sıra bir kuşakla çevrilir. Halının kısa kenarlarında ise ev motifli ince şeritler görülür.

19. yüzyıl Karapınar halılarına baktı̆̆ımızda, kompozisyonda ana hatlarıyla bir değişiklik olmamasına rağmen, 18. yüzyılda görülen sadelikten uzaklaşıldığı, zeminin ve kuşakların bezemesinde yeni, yöreye has olmayan motiflerle kalabalıklaştı̆̆g görülmektedir. 18. yüzyıl örneklerinin karakteristik özelliklerinden sayılabilecek, çivit mavisi ve kırmızı renklerin, 19. yüzyıl örneklerinde renk özelliklerini yitirdikleri benzer tonlara dönüştüğü görülür.

Türkiye'nin önemli dokuma merkezleri arasında sayılan Karapınar'ın; geleneksel Türk halı sanatı içerisinde yer alan, yöreye özgü özellikler taşıyan halıları 19. Yüzyıldan itibaren diğer yörelerimizin pek çoğunda olduğu gibi özelliklerini yitirmeye başlamış, günümüzde ise yok olma noktasına gelmiştir.

\section{Kaynaklar}

Bodur, Fulya (1984), "Karapinar Halıcılığı", Türk Dünyast Araştırmalan, Türk Hahlan Özel Sayıst, Say1 32, İstanbul, s.73-81.

Erdmann, Kurt (basım tarihi yok), Der Türkische Teppich Des 15. Jahrhunderts, IÇeviren: H. Taner, 15. Asır Türk Hal1s1), İstanbul.

Gündüz, Ibrahim (1980), Bütün Yönleriyle Karapinar, Konya. Gündüz, İbrahim (1993), Karapinar El Dokumalan ve Kökboyactlik, Konya: Karapınar Belediyesi Kültür Yayını, No: 2. Küçükdağ, Yusuf (2001), “Karapınar Kasabasının Kurulma S1 ve İskan Durumu", Türkiye Büyük Millet Meclisinin Açilşınin 80. Yildönümü Karapinar Sempozyumu (Karaptnar, 26-27 Ekim 2000), Editör: Yusuf Küçükdağ, Konya, s. 8-15.

Ögel, Bahaeddin (1989), Türk Mitolojisi, Cilt I, Ankara: Türk Tarih Kurumu

Sümer, Faruk (1992), Oğuzlar (Türkmenler) Tarihleri-Boy Teşkilatı-Destanları, İstanbul. 


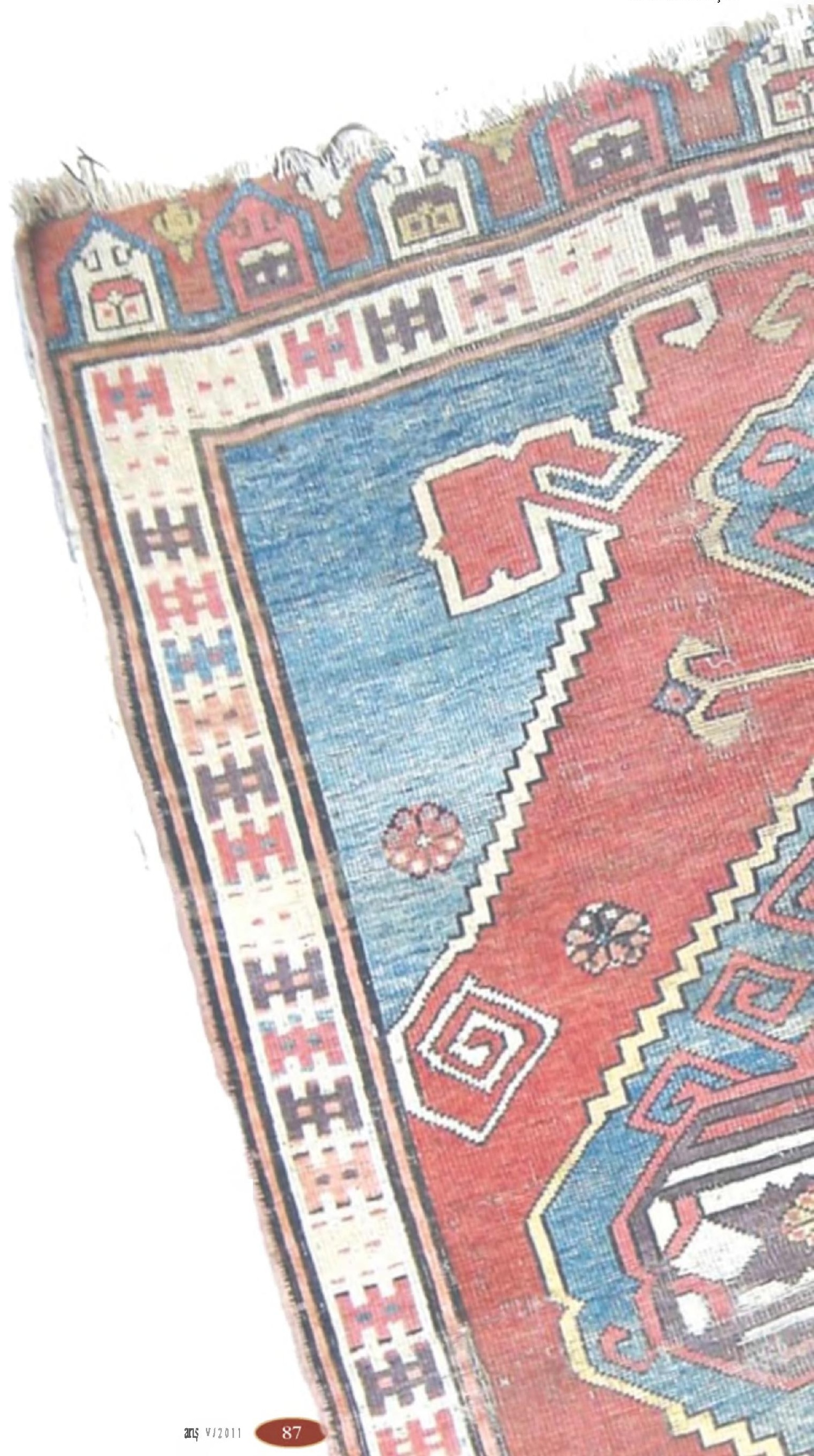

